\title{
Current Insights into Combination Therapies with MAPK Inhibitors and Immune Checkpoint Blockade
}

\author{
Min Hwa Shin ${ }^{+}{ }^{\mathbb{C}}$, Jiyoung $\mathrm{Kim}^{\dagger}{ }^{\dagger}$, Siyoung A. Lim, Jeongsoo Kim and Kyung-Mi Lee *(1) \\ Department of Biochemistry and Molecular Biology, College of Medicine, Korea University, Seoul 02841, Korea; \\ mhshin0423@gmail.com (M.H.S.); jjyoung0121@gmail.com (J.K.); s.abby.lim18@gmail.com (S.A.L.); \\ kjs5043@gmail.com (J.K.) \\ * Correspondence: kyunglee@korea.ac.kr \\ † These authors contributed equally to this work.
}

Received: 1 March 2020; Accepted: 3 April 2020; Published: 5 April 2020

\begin{abstract}
The recent development of high-throughput genomics has revolutionized personalized medicine by identifying key pathways and molecular targets controlling tumor progression and survival. Mitogen-activated protein kinase (MAPK) pathways are examples of such targets, and inhibitors against these pathways have shown promising clinical responses in patients with melanoma, non-small-cell lung cancer, colorectal cancer, pancreatic cancer, and thyroid cancer. Although MAPK pathway-targeted therapies have resulted in significant clinical responses in a large proportion of cancer patients, the rate of tumor recurrence is high due to the development of resistance. Conversely, immunotherapies have shown limited clinical responses, but have led to durable tumor regression in patients, and complete responses. Recent evidence indicates that MAPK-targeted therapies may synergize with immune cells, thus providing rationale for the development of combination therapies. Here, we review the current status of ongoing clinical trials investigating MAPK pathway inhibitors, such as BRAF and MAPK/ERK kinase (MEK) inhibitors, in combination with checkpoint inhibitors targeting programmed death protein 1 (PD-1), programmed death-ligand 1 (PD-L1), and cytotoxic T cell associated antigen-4 (CTLA-4). A better understanding of an individual drug's mechanism of action, patterns of acquired resistance, and the influence on immune cells will be critical for the development of novel combination therapies.
\end{abstract}

Keywords: combination therapy; MAPK targeted therapy; BRAF inhibitor; MEK inhibitor; immune checkpoint inhibitor; PD-1; PD-L1; CTLA-4

\section{Introduction}

In recent years, the focus of cancer therapeutics has shifted from the treatment of cancers based on type and histology to those targeting specific gene mutation and its dysregulation. Accordingly, cancer treatment regimens have advanced considerably with the development of specific inhibitors aimed at oncogenic and mutated proteins [1]. Table 1 summarizes the tumor-driver mutations identified in melanoma, non-small-cell lung cancer (NSCLC), colorectal cancer (CRC), pancreatic cancer, and thyroid cancer [2]. 
Table 1. Genetic drivers of cancer.

\begin{tabular}{cc}
\hline Type of Cancer & Mutations \\
\hline Melanoma & $I D H 1, R B 1$, DDX3X, NF1, BRAF, RAS, \\
\hline Non-small-cell lung cancer & $P I 3 K, F G F R, D D R 2, P T E N$, KRAS, EGFR, BRAF, ALK \\
\hline Colorectal cancer & $A P C, K R A S, T P 53$, SMAD4, FBXW7, BRAF, PI3K \\
\hline Pancreatic cancer & $K R A S, B R A F, T P 53$, CDKN2A, SMAD4, MLL3, TGFBR2, ARID1A, SF3B1 \\
\hline Thyroid cancer & $R A S, B R A F, T P 53$, PI3K, RET/PTC \\
\hline
\end{tabular}

Due to the genetic heterogeneity of cancer, standard treatments, including chemotherapy and radiation, are effective only in a subset of patients diagnosed early and with tumors that have low invasive properties. This inherent heterogeneity of cancer lends itself to the growing field of precision and personalized medicine. Personalized therapies could inhibit cancer growth and at the same time increase antitumor immunity in patients more efficiently. Targeted therapies and immunotherapies are two approaches that can generate individualized treatment. Targeted therapies target various oncogenic proteins that contribute to cancer development. Although these targeted therapies can lead to a substantial reduction of tumor size in various cancers, clinical responses tend to be temporary, and often result in tumor escape and relapse after initial treatment. Table 2 summarizes targeted therapies approved by the United States (US) Food and Drug Administration (FDA) for the treatment of cancer [2].

Compared to targeted therapy, immunotherapy has demonstrated more enduring responses in patients with multiple types of cancer. Notably, checkpoint blockade, one form of immunotherapy, has been shown to lead to long-lasting responses; however, the response rate is lower than that of targeted therapies. Checkpoint blockade therapies target checkpoint proteins, which are involved in suppressing the immune system. Table 3 summarizes FDA-approved monoclonal antibodies (mAbs) and their targets for checkpoint blockade, as well as other antitumor immunotherapies [2].

Despite the benefits of targeted therapies and immunotherapies, they are also associated with a number of limitations. Such limitations may be overcome by combining a targeted therapy and an immunotherapy [3], and several clinical trials investigating combination therapy are ongoing to assess the safety and efficacy of these approaches. Here, we review the current status of therapies targeting the MAPK pathway and immunotherapies, mainly focusing on melanoma and NSCLC, as well as other solid cancers, such as pancreatic cancer, CRC, and thyroid cancer (clinicaltrials.gov). Major drivers of these cancers include BRAF (V600E, V599E) and/or KRAS (G12C, G12D) along the MAPK pathways while immunotherapies were considered as a monotherapy or in combination in those tumors expressing PD-1 ligands. Melanoma and NSCLC were chosen since they were shown to be refractory to conventional treatment but exhibited long-lasting responses to immunotherapies. Furthermore, colorectal cancer patients with microsatellite instability were shown to benefit from anti-PD-1 therapy while some of these patients also express BRAF V600E [4]. In addition to these cancers, drivers of pancreatic cancers and thyroid cancers have been shown to exhibit KRAS (G12C, G12D) and BRAF (V599E) among MAPK pathways [5]. Therefore, we expect that combination of MAPK-targeted therapies with immune checkpoint blockades could potentially compensate and synergize each other to produce long lasting antitumor effects. 
Table 2. Food and Drug Administration (FDA)-approved targeted therapies for cancer.

\begin{tabular}{|c|c|c|c|}
\hline Name of Drug & Company & Target & Conditions \\
\hline Everolimus (Afinitor) & Novartis & mTOR & $\begin{array}{l}\text { - Pancreatic, gastrointestinal, or lung origin } \\
\text { neuroendocrine tumors } \\
\text { - } \quad \text { Renal cell carcinoma } \\
\text { - Nonresectable subependymal giant cell astrocytoma } \\
\text { associated with tuberous sclerosis } \\
\text { - Breast cancer (HR+, HER2-) }\end{array}$ \\
\hline Lapatinib (Tykerb) & GlaxoSmithKline & $\begin{array}{c}\text { HER2 (ERBB2/neu), EGFR } \\
\text { (HER1/ERBB1) }\end{array}$ & - $\quad$ Breast cancer (HER2+) \\
\hline Neratinib (Nerlynx) & Puma Biotech & HER2 (ERBB2/neu) & - $\quad$ Breast cancer (HER2 overexpressed/amplified) \\
\hline Palbociclib (Ibrance) & Pfizer & CDK4, CDK6 & - $\quad$ Breast cancer $(\mathrm{HR}+$, HER2-) \\
\hline Ribociclib (Kisqali) & Novartis & CDK4, CDK6 & - $\quad$ Breast cancer $(\mathrm{HR}+, \mathrm{HER} 2-)$ \\
\hline $\begin{array}{l}\text { Ado-trastuzumab emtansine } \\
\qquad \text { (Kadcyla) }\end{array}$ & Genentech & HER2 (ERBB2/neu) & - $\quad$ Breast cancer (HER2+) \\
\hline Trastuzumab (Herceptin) & Genentech & HER2 (ERBB2/neu) & $\begin{array}{ll}\text { - } & \text { Breast cancer (HER2+) } \\
\text { - } & \text { Gastric cancer (HER2+) }\end{array}$ \\
\hline Erdafitinib (Balversa ${ }^{\mathrm{TM}}$ ) & $\begin{array}{l}\text { Astex Pharmaceuticals and } \\
\text { Janssen Pharmaceutical }\end{array}$ & FGFR & - Urothelial carcinoma \\
\hline Axitinib (Inlyta) & Chiron & KIT, PDGFR $\beta$, VEGFR1/2/3 & - $\quad$ Renal cell carcinoma \\
\hline Lenvatinib (Lenvima) & Eisai & VEGFR2 & $\begin{array}{ll}\text { - } & \text { Renal cell carcinoma } \\
\text { - } & \text { Thyroid cancer }\end{array}$ \\
\hline
\end{tabular}


Table 2. Cont.

\begin{tabular}{|c|c|c|c|}
\hline Name of Drug & Company & Target & Conditions \\
\hline Sorafenib (Nexavar) & Bayer & VEGFR, PDGFR, KIT, RAF & $\begin{array}{ll}\text { - } & \text { Hepatocellular carcinoma } \\
\text { - } & \text { Renal cell carcinoma } \\
\text { - } & \text { Thyroid carcinoma }\end{array}$ \\
\hline Temsirolimus (Torisel) & Pfizer & mTOR & - Renal cell carcinoma \\
\hline Pazopanib (Votrient) & GlaxoSmithKline & VEGFR, PDGFR, KIT & - $\quad$ Renal cell carcinoma \\
\hline $\begin{array}{l}\text { Cabozantinib (Cabometyx } \\
\text { (tablet), Cometriq (capsule])) }\end{array}$ & Exelixis & FLT3, KIT, MET, RET, VEGFR2 & $\begin{array}{l}\text { - } \quad \text { Medullary thyroid cancer } \\
\text { - } \quad \text { Renal cell carcinoma }\end{array}$ \\
\hline Afatinib (Gilotrif) & Boehringer Ingelheim & $\begin{array}{l}\text { EGFR (HER1/ERBB1), HER2 } \\
\text { (ERBB2/neu) }\end{array}$ & $\begin{array}{l}\text { - Non-small-cell lung cancer (with EGFR exon } 19 \\
\text { deletions or exon } 21 \text { substitution (L858R) mutations) }\end{array}$ \\
\hline Alectinib (Alecensa) & Genentech & ALK & - $\quad$ Non-small-cell lung cancer (with ALK fusion) \\
\hline Brigatinib (Alunbrig) & Takeda Pharmaceutical & ALK & - $\quad$ Non-small-cell lung cancer (ALK+) \\
\hline Ceritinib (Zykadia) & Novartis & ALK & - $\quad$ Non-small-cell lung cancer (with ALK fusion) \\
\hline Crizotinib (Xalkori) & Pfizer & ALK, MET, ROS1 & $\begin{array}{l}\text { - Non-small-cell lung cancer (with ALK fusion or ROS1 } \\
\text { gene alteration) }\end{array}$ \\
\hline Erlotinib (Tarceva) & Roche & EGFR (HER1/ERBB1) & $\begin{array}{ll}\text { - } & \text { Non-small-cell lung cancer (with EGFR exon } 19 \\
\text { deletions or exon } 21 \text { substitution (L858R) mutations) } \\
\text { - } \quad \text { Pancreatic cancer }\end{array}$ \\
\hline Gefitinib (Iressa) & AstraZeneca & EGFR (HER1/ERBB1) & $\begin{array}{l}\text { - Non-small-cell lung cancer (with EGFR exon } 19 \\
\text { deletions or exon } 21 \text { substitution (L858R) mutations) }\end{array}$ \\
\hline
\end{tabular}


Table 2. Cont.

\begin{tabular}{|c|c|c|c|}
\hline Name of Drug & Company & Target & Conditions \\
\hline Osimertinib (Tagrisso) & AstraZeneca & EGFR & $\begin{array}{l}\text { - Non-small-cell lung cancer (with EGFR } \\
\text { T790M mutation) }\end{array}$ \\
\hline Cobimetinib (Cotellic) & Genentech & MEK & - $\quad$ Melanoma (with BRAF V600E or V600K mutation) \\
\hline Dabrafenib (Tafinlar) & GlaxoSmithKline & BRAF & $\begin{array}{l}\text { - } \quad \text { Melanoma (with BRAF V600 mutation) } \\
\text { Non-small-cell lung cancer (with BRAF } \\
\text { V600E mutation) }\end{array}$ \\
\hline Necitumumab (Portrazza) & Eli Lilly & EGFR (HER1/ERBB1) & - Squamous non-small-cell lung cancer \\
\hline Bortezomib (Velcade) & Takeda & Proteasome & $\begin{array}{ll}\text { - } & \text { Multiple myeloma } \\
\text { - } & \text { Mantle cell lymphoma }\end{array}$ \\
\hline Bosutinib (Bosulif) & Pfizer & $\mathrm{ABL}$ & $\begin{array}{l}\text { - Chronic myelogenous leukemia (Philadelphia } \\
\text { chromosome positive) }\end{array}$ \\
\hline Carfilzomib (Kyprolis) & Onyx & Proteasome & - $\quad$ Multiple myeloma \\
\hline Dasatinib (Sprycel) & Bristol-Myers Squibb & ABL & $\begin{array}{l}\text { - Chronic myelogenous leukemia (Philadelphia } \\
\text { chromosome positive) } \\
\text { - Acute lymphoblastic leukemia (Philadelphia } \\
\text { chromosome positive) }\end{array}$ \\
\hline Enasidenib (Idhifa) & $\begin{array}{c}\text { Agios } \\
\text { Pharmaceuticals/Celgene }\end{array}$ & $\mathrm{IDH} 2$ & - $\quad$ Acute myeloid leukemia (with IDH2 mutation) \\
\hline Venetoclax (Venclexta) & AbbVie and Roche & BCL2 & - Chronic lymphocytic leukemia (with $17 p$ deletion) \\
\hline
\end{tabular}


Table 2. Cont

\begin{tabular}{|c|c|c|c|}
\hline Name of Drug & Company & Target & Conditions \\
\hline Ibrutinib (Imbruvica) & Johnson \&Johnson & BTK & $\begin{array}{l}\text { - } \quad \text { Mantle cell lymphoma } \\
\text { - } \quad \text { Chronic lymphocytic leukemia } \\
\text { - } \quad \text { Waldenstrom's macroglobulinemia }\end{array}$ \\
\hline Idelalisib (Zydelig) & Gilead & PI3K $\delta$ & $\begin{array}{ll}\text { - } & \text { Chronic lymphocytic leukemia } \\
\text { - } & \text { Follicular B-cell non-Hodgkin's lymphoma } \\
\text { - } & \text { Small lymphocytic lymphoma }\end{array}$ \\
\hline Ixazomib (Ninlaro) & Takeda Pharmaceutical & Proteasome & - $\quad$ Multiple myeloma \\
\hline Midostaurin (Rydapt) & Novartis & FLT3 & - $\quad$ Acute myeloid leukemia (FLT3+) \\
\hline Nilotinib (Tasigna) & Novartis & $\mathrm{ABL}$ & $\begin{array}{l}\text { - Chronic myelogenous leukemia (Philadelphia } \\
\text { chromosome positive) }\end{array}$ \\
\hline Trametinib (Mekinist) & GlaxoSmithKline & MEK & $\begin{array}{l}\text { - } \quad \text { Melanoma (with BRAF V600 mutation) } \\
\text { Von-small-cell lung cancer (with BRAF } \\
\text { V600E mutation) }\end{array}$ \\
\hline Vemurafenib (Zelboraf) & Genentech & BRAF & - $\quad$ Melanoma (with BRAF V600 mutation) \\
\hline Cetuximab (Erbitux) & Eli Lilly & EGFR (HER1/ERBB1) & $\begin{array}{l}\text { - } \quad \text { Colorectal cancer (KRAS wild type) } \\
\text { - } \quad \text { Squamous cell cancer of the head and neck }\end{array}$ \\
\hline Ziv-aflibercept (Zaltrap) & Sanofi-Aventis & PIGF, VEGFA/B & - Colorectal cancer \\
\hline
\end{tabular}


Table 2. Cont

\begin{tabular}{|c|c|c|c|}
\hline Name of Drug & Company & Target & Conditions \\
\hline Panitumumab (Vectibix) & Amgen & EGFR (HER1/ERBB1) & - $\quad$ Colorectal cancer (KRAS wild type) \\
\hline Regorafenib (Stivarga) & Bayer & $\begin{array}{c}\text { KIT, PDGFR } \beta, \text { RAF, RET, } \\
\text { VEGFR1-3 }\end{array}$ & $\begin{array}{ll}\text { - } & \text { Colorectal cancer } \\
\text { - } & \text { Gastrointestinal stromal tumors } \\
\text { - } & \text { Hepatocellular carcinoma }\end{array}$ \\
\hline Rucaparib (Rubraca) & Clovis Oncology & PARP & - $\quad$ Ovarian cancer (with BRCA mutation) \\
\hline Niraparib (Zejula) & Tesaro & PARP & $\begin{array}{ll}\text { - } & \text { Ovarian cancer } \\
\text { - } & \text { Fallopian tube cancer } \\
\text { - } & \text { Peritoneal cancer }\end{array}$ \\
\hline Olaparib (Lynparza) & AstraZeneca & PARP & - Ovarian cancer (with BRCA mutation) \\
\hline Denosumab (Xgeva) & Amgen & RANKL & - Giant cell tumor of the bone \\
\hline Dinutuximab (Unituxin) & United Therapeutics & B4GALNT1 (GD2) & - $\quad$ Pediatric neuroblastoma \\
\hline Imatinib (Gleevec) & Novartis & KIT, PDGFR, ABL & $\begin{array}{ll}\text { - } & \text { GI stromal tumor }(\mathrm{KIT}+) \\
\text { - } & \text { Dermatofibrosarcoma protuberans } \\
& \text { Philiple hematological malignancies including } \\
& \text { Phromosome-positive ALL and CML }\end{array}$ \\
\hline Sonidegib (Odomzo) & Novartis & Smoothened & - $\quad$ Basal cell carcinoma \\
\hline
\end{tabular}


Table 2. Cont.

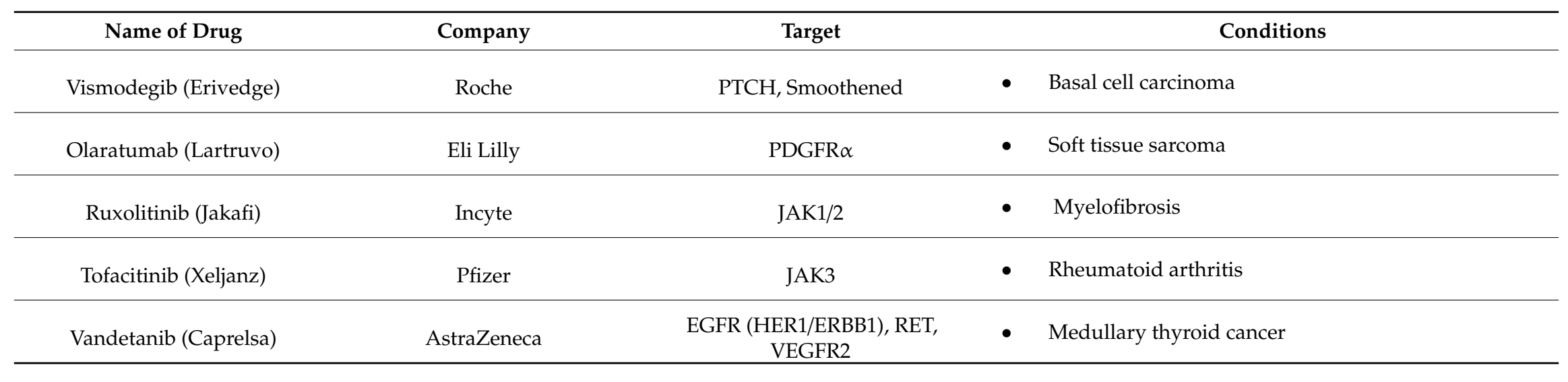

Table 3. FDA-approved drugs for immunotherapy.

\begin{tabular}{|c|c|c|c|}
\hline Name of Drug & Company & Target & Conditions \\
\hline Alemtuzumab (Campath) & Sanofi & CD52 & - B-cell chronic lymphocytic leukemia \\
\hline Atezolizumab (Tecentriq) & Genentech & PD-L1 & $\begin{array}{l}\text { - Urothelial carcinoma } \\
\text { - } \quad \text { Non-small-cell lung cancer }\end{array}$ \\
\hline Avelumab (Bavencio) & Merck KGaA and Pfizer & PD-L1 & $\begin{array}{ll}\text { - } & \text { Merkel cell carcinoma } \\
\text { - } & \text { Urothelial cancer }\end{array}$ \\
\hline Blinatumomab (Blincyto) & Amgen & CD19/CD3 & - $\quad$ Acute lymphoblastic leukemia (precursor B-cell) \\
\hline Brentuximab vedotin (Adcetris) & Takeda Pharmaceutical & CD30 & $\begin{array}{ll}\text { - } & \text { Hodgkin lymphoma } \\
\text { - } & \text { Anaplastic large cell lymphoma }\end{array}$ \\
\hline
\end{tabular}


Table 3. Cont.

\begin{tabular}{|c|c|c|c|}
\hline Name of Drug & Company & Target & Conditions \\
\hline Canakinumab (Ilaris) & Novartis & IL-1 $\beta$ & $\begin{array}{ll}\text { - } & \text { Juvenile idiopathic arthritis } \\
\text { - } & \text { Cryopyrin-associated periodic syndromes }\end{array}$ \\
\hline Daratumumab (Darzalex) & Janssen Pharmaceutical & CD38 & - $\quad$ Multiple myeloma \\
\hline Durvalumab (Imfinzi) & MedImmune/AstraZeneca & PD-L1 & $\begin{array}{ll}\text { - } & \text { Urothelial carcinoma } \\
\text { - } & \text { Non-small-cell lung cancer }\end{array}$ \\
\hline Elotuzumab (Empliciti) & Bristol-Myers Squibb & $\begin{array}{c}\text { SLAMF7 } \\
\text { (CS1/CD319/CRACC) }\end{array}$ & - $\quad$ Multiple myeloma \\
\hline Ibritumomab tiuxetan (Zevalin) & Biogen IDEC & CD20 & - Non-Hodgkin's lymphoma \\
\hline Ipilimumab (Yervoy) & Bristol-Myers Squibb & CTLA-4 & $\begin{array}{ll}\text { - } & \text { Melanoma } \\
\text { - } & \text { Renal cell carcinoma }\end{array}$ \\
\hline Nivolumab (Opdivo) & Bristol-Myers Squibb & PD-1 & $\begin{array}{ll}\text { - } & \text { Colorectal cancer (dMMR and MSI-H) } \\
\text { - } & \text { Head and neck squamous cell carcinoma } \\
\text { - } & \text { Hepatocellular carcinoma } \\
\text { - } & \text { Hodgkin lymphoma } \\
\text { - } & \text { Melanoma } \\
\text { - } & \text { Non-small-cell lung cancer } \\
\text { - } & \text { Renal cell carcinoma } \\
\text { - } & \text { Urothelial carcinoma }\end{array}$ \\
\hline Obinutuzumab (Gazyva) & Roche & CD20 & $\begin{array}{l}\text { - } \quad \text { Chronic lymphocytic leukemia } \\
\text { - } \quad \text { Follicular lymphoma }\end{array}$ \\
\hline $\begin{array}{l}\text { Ofatumumab (Arzerra, } \\
\text { HuMax-CD20) }\end{array}$ & Roche & CD20 & - Chronic lymphocytic leukemia \\
\hline
\end{tabular}


Table 3. Cont.

\begin{tabular}{|c|c|c|c|}
\hline Name of Drug & Company & Target & Conditions \\
\hline Pembrolizumab (Keytruda) & Merck \&Co & PD-1 & $\begin{array}{ll}\text { - } & \text { Classical Hodgkin lymphoma } \\
\text { - } & \text { Colorectal cancer (MSI-H/dMMR) } \\
\text { - } & \text { Gastric cancer } \\
\text { - } & \text { Melanoma } \\
\text { - } & \text { Non-small-cell lung cancer (PD-L1+) } \\
\text { - } & \text { Head and neck squamous cell carcinoma } \\
\text { - } & \text { Urothelial cancer } \\
\text { - } & \text { Solid tumors (MSI-H/dMMR) }\end{array}$ \\
\hline Rituximab (Rituxan, Mabthera) & Roche & CD20 & $\begin{array}{ll}\text { - } & \text { Non-Hodgkin's lymphoma } \\
\text { - } & \text { Chronic lymphocytic leukemia } \\
\text { - } & \text { Rheumatoid arthritis } \\
\text { - } & \text { Granulomatosis with polyangiitis }\end{array}$ \\
\hline $\begin{array}{l}\text { Rituximab/hyaluronidase } \\
\text { human (Rituxan Hycela) }\end{array}$ & Roche & CD20 & $\begin{array}{ll}\text { - } & \text { Chronic lymphocytic leukemia } \\
\text { - } & \text { Diffuse large B-cell lymphoma } \\
\text { - } & \text { Follicular lymphoma }\end{array}$ \\
\hline Siltuximab (Sylvant) & Janssen Pharmaceutical & IL-6 & - Multicentric Castleman's disease \\
\hline Tocilizumab (Actemra) & Genentech & IL-6R & $\begin{array}{ll}\text { - } & \text { Rheumatoid arthritis } \\
\text { - } & \text { Juvenile idiopathic arthritis }\end{array}$ \\
\hline Tositumomab (Bexxar) & Corixa & CD20 & - $\quad$ Non-Hodgkin's lymphoma \\
\hline
\end{tabular}




\section{Therapies Targeting the MAPK Pathway}

Major advances have been made in the treatment of cancer through genetic and genomic tools to investigate the mechanisms of progression of several types of cancer. Targeting the MAPK pathway is a therapeutic approach aimed at oncogenic and mutated/dysregulated proteins. The main targets of these treatments have been the MEK (MAPK/ERK kinase) and BRAF proteins in the MAPK pathway. A schematic illustration of the MAPK signaling pathway and FDA-approved inhibitors of this pathway is shown in Figure 1.

In melanoma, an activating point mutation at V600 in BRAF is the main oncogenic driver [6,7]. This BRAF mutation activates signaling of the MAPK pathway, and promotes cancer cell proliferation and immune escape $[8,9]$.

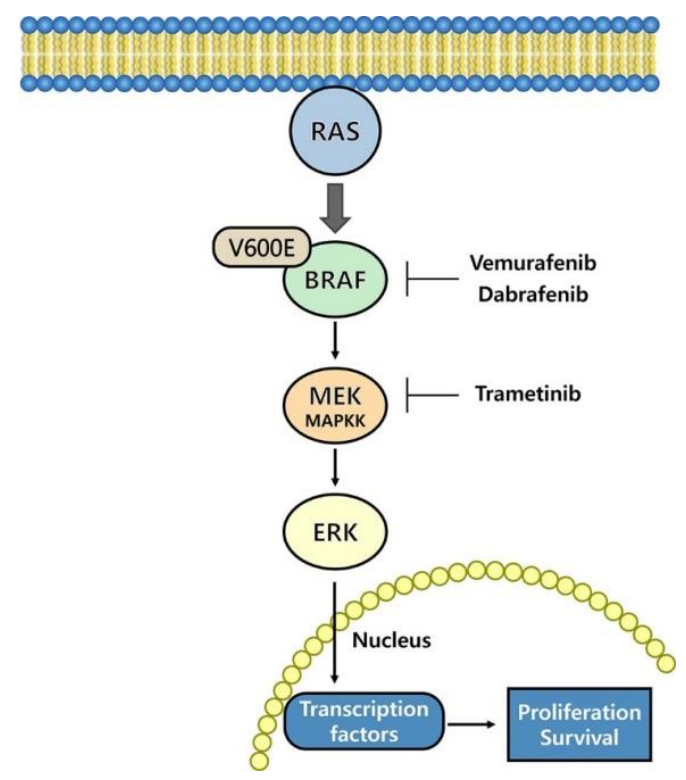

Figure 1. Mitogen-activated protein kinase (MAPK) pathways and BRAF and MAPK/ERK kinase (MEK) inhibitors.

Subsequently, BRAF inhibitors were developed for the treatment of patients with melanoma. However, one of the early BRAF inhibitors, sorafenib, demonstrated toxicity, including non-specific side effects, and resulted in low clinical responses in patients with melanoma [10]. A more effective inhibitor (vemurafenib) was later developed targeting the V600-mutated site of BRAF; this demonstrated favorable responses and resulted in an increased rate of overall survival (OS) in multiple clinical trials [11]. Dabrafenib, which also targets the BRAF V600 mutation in melanoma, has demonstrated improved OS in clinical trials [12]. Vemurafenib and dabrafenib were approved by the FDA as monotherapies in 2011 and 2013, respectively. Initial in vitro and in vivo studies using BRAF-targeted therapies demonstrated increased melanoma antigen expression with tumor-infiltrating CD8+ T cells, and decreased levels of VEGF and immunosuppressive cytokines. These findings demonstrate heightened CD8+ T cell targeting to tumors as well as increased levels of granzyme B and perforin-two proteases that control T cell-induced tumor apoptosis [12].

For patients without the BRAF mutation, an inhibitor of MEK-a kinase downstream of RAF in the MAPK-signaling pathway-such as trametinib (FDA approved in 2013), demonstrated favorable clinical responses [13]. MEK inhibitors can induce melanocyte-inducing transcription factor (MITF) and melanocyte-derived antigen expression, and enhance T cell infiltration to tumors similar to BRAF inhibitors. MEK inhibitors were also shown to generate an antitumor immune response by hindering the interaction between tumor cells and M2-like macrophages, thus allowing the tumor-specific effector T-cells to be trafficked to tumors [14]. 
A major issue with both BRAF and MEK inhibitors is the development of gene resistance to the drugs. To reduce this resistance, combination therapy with a BRAF and a MEK inhibitor has been developed as a therapeutic approach for melanoma patients with the BRAF mutation. This combination aims to overcome resistance to a single inhibitor by focusing on vertical elements along the MAPK pathway. Combined treatment with BRAF and MEK inhibitors is currently approved, but only small advances in progression-free survival (PFS) and OS compared with BRAF inhibitor monotherapy have been reported. However, resistance continues to be an issue [15].

Inhibition of the MAPK pathway in both BRAF-mutant and wild-type melanoma cells resulted in increased tumor antigen expression and T-cell function [7]. Patients with melanoma treated with a BRAF inhibitor have also demonstrated enhanced antigen expression in tumors [16]. The immune effects of MAPK pathway inhibitors are reported to affect $T$ cells and dendritic cells, regardless of the BRAF mutation status [17]. Patients treated with BRAF inhibitors have demonstrated preserved T cell activity and viability, highlighting their potential combination with immunotherapy [18]. However, the immune response to BRAF-targeted therapies occurs early, but this response is lost upon tumor progression [19]. Furthermore, PD-1 and Tim-3 expression were found to be increased in T cells and in their corresponding ligands in tumors [20]. These phenotypes support the rationale for combination therapy with a MAPK-targeted inhibitor and immune checkpoint blockade (anti-PD-1, anti-PDL-1, or Tim-3).

\section{Immune Checkpoint Blockade}

Cancer immunotherapy aims to improve the ability of the patients' immune system to destroy tumor cells. The first immunotherapy regimen developed used interleukin 2 (IL-2) to treat patients with metastatic melanoma [21]. IL-2 has been reported to increase T-cell activation in a non-specific manner [9]. However, due to the serious toxicity and low response rates, high doses of IL-2 are now rarely used as monotherapy [22]; however, low-dose IL-2 in combination with other therapies, such as adoptive cell transfer, have demonstrated therapeutic efficacy [23].

Immune checkpoints represent an area of cancer immunotherapies for which treatments are being developed. The major function of immune checkpoints is to limit immune cell activation to maintain immune homeostasis while inhibiting the development of autoimmunity. Immune checkpoint molecules are upregulated by tumor cells within the tumor microenvironment to repress the anti-cancer response of the immune system. Therefore, the use of specific mAbs to block immune checkpoints is expected to reverse the suppression of tumor-specific immune cells, including $\mathrm{T}$ cells and natural killer (NK) cells $[24,25]$. Monoclonal antibodies against immune checkpoint receptors, such as CTLA-4, PD-1, and PD-L1, have demonstrated significant results in the treatment of multiple advanced cancers, including melanoma, NSCLC, head and neck, and bladder cancers [26]. The interactions of PD-1, PD-L1, and CTLA-4 with their cognate ligands and clinical trials with various inhibitors are illustrated in Figure 2 and Table 4, respectively.

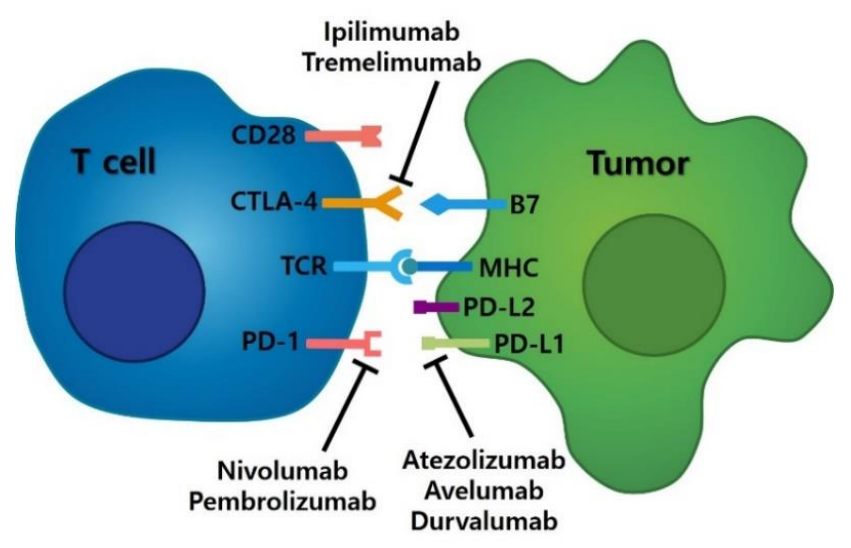

Figure 2. Checkpoint inhibition with PD-1, PD-L1, and CTLA-4 blockade. 
Table 4. FDA-approved checkpoint inhibitors.

\begin{tabular}{|c|c|c|c|}
\hline Name of Drug & Company & Target & Indications \\
\hline Ipilimumab & Bristol-Myers Squibb & CTLA-4 & - Unresectable or metastatic melanoma \\
\hline Tremelimumab & AstraZeneca & CTLA-4 & $\begin{array}{l}\text { - Unresectable malignant mesothelioma } \\
\text { - } \quad \text { Metastatic melanoma } \\
\text { - } \quad \text { Non-small-cell lung cancer }\end{array}$ \\
\hline Nivolumab & Bristol-Myers & PD-1 & $\begin{array}{ll}\text { - } & \text { Unresectable or metastatic melanoma } \\
\text { - } & \text { Metastatic non-small-cell lung cancer } \\
\text { - } & \text { Recurrent or metastatic head and neck } \\
\text { - } & \text { squamous cell carcinoma } \\
\text { - } & \text { Hecally advanced or metastatic carcinoma } \\
\text { Hepatocarcinoma }\end{array}$ \\
\hline Pembrolizumab & Merck & PD-1 & $\begin{array}{l}\text { - } \quad \text { Unresectable or metastatic melanoma } \\
\text { - } \quad \text { notastatic non-squamous } \\
\text { - } \quad \text { Recurrent or metastatic head and neck } \\
\text { - } \quad \text { Refractory Hous cell carcinoma } \\
\text { - } \quad \text { Locally advanced or metastatic } \\
\text { urothelial carcinoma }\end{array}$ \\
\hline Atezolizumab & Roche & PD-L1 & $\begin{array}{l}\text { - Advanced or metastatic } \\
\text { urothelial carcinoma } \\
\text { - } \quad \text { Metastatic non-small-cell lung cancer }\end{array}$ \\
\hline Avelumab & Merck Pfizer & PD-L1 & $\begin{array}{l}\text { Locally advanced or metastatic } \\
\text { urothelial carcinoma }\end{array}$ \\
\hline Durvalumab & MedImmune/AstraZeneca & PD-L1 & $\begin{array}{l}\text { - Urothelial carcinoma } \\
\text { - } \quad \text { Non-small-cell lung cancer }\end{array}$ \\
\hline
\end{tabular}

Ipilimumab, a monoclonal antibody against CTLA-4, was the first inhibitor developed for the treatment of patients with stage IV melanoma [27]. CLTA-4 prevents early T-cell activation; it is not present on resting $T$ cells but is upregulated immediately upon $T$ cell activation [9]. CTLA-4 competes with CD28 for their shared ligands, B7-1 and B7-2 (also known as CD80 and CD28, respectively), resulting in the negative regulation of T-cell signaling [28]. PD-1 is another immune checkpoint molecule. Similar to CTLA-4, PD-1 is generally upregulated on activated T cells [29], and negatively regulates T-cell receptor signaling and tumor killing functions by interacting with PD-L1 and PD-L2 [30]. Crosslinking of PD-1 also increases the apoptosis of cytotoxic T cells [31]. PD-1 blockade (for example, with nivolumab) has been investigated in multiple clinical trials in patients with melanoma, NSCLC, and CRC [32]. Patients with advanced melanoma enrolled in trials investigating PD-1 therapies have demonstrated a response rate of $28 \%$, with durable results lasting more than 1 year in $50 \%$ of responding patients [33].

When used as monotherapy, currently approved checkpoint inhibitors do not lead to durable clinical responses in almost $80 \%$ of cancer patients. Patients who responded well to checkpoint therapy often had a significant number of tumor-infiltrating $\mathrm{T}$ cells before starting treatment. Thus, a limitation of checkpoint therapy is the lack of available activated $\mathrm{T}$ cells that can respond to the 
therapy. In addition, cancers that demonstrate an initial response may become resistant to checkpoint therapy, which would further reduce treatment efficacy [34].

Among anti-CTLA-4 and PD-1 treatments, the latter have been shown to be more effective. A study comparing ipilimumab with pembrolizumab (another PD-1 antibody) reported 6-month PFS of 26.5\% and $47.3 \%$, respectively. Anti-PD-1 therapies have also been shown to result in fewer adverse events compared with anti-CTLA-4 therapies. This is likely due to the expression of PD-1 on mature T cells (such as dendritic cells and macrophages), while CLTA-4 is present on T cells throughout the body, including those in the lymph nodes and skin [35].

Combination therapy using PD-1 and CLTA- 4 antibodies has been studied to enhance efficacy and reduce toxicity. Since CTLA-4 and PD-1 therapies function through different mechanisms, their use in combination can generate a synergistic effect, thus limiting the side effects from a single checkpoint inhibitor. Checkpoint monotherapy also has been shown to activate alternative T-cell checkpoints; thus, therapy targeting one checkpoint will result in the upregulation of another checkpoint, which may exacerbate tumor effects [35]. Recent clinical trials showed that blocking CTLA-4 and PD-1 simultaneously in patients with advanced melanoma strengthened the function of tumor-specific $T$ cells, but resulted in off-target/on-target side effects [36]. Consequently, alternative combinations with other checkpoint inhibitors or targeted therapies are being developed in an attempt to reduce toxicities.

\section{Combination of Immunotherapy and Targeted Therapy}

Melanomas, like many types of cancer, are capable of evading cell death by suppressing the immune system. One of these mechanisms involves the activation of PD-L1 expression by the release of cytokines (such as interferon-gamma) in tumor-infiltrating lymphocytes (TILs). Immune resistance has been demonstrated in BRAF inhibitor-resistant melanoma cell lines with increased PD-L1 expression, which permitted host immune cell evasion [15]. Despite the development of resistance, in the early stages of treatment, BRAF (and MAPK) inhibitors can stimulate the immune response against tumors.

BRAF and MEK inhibitors can also enhance intratumoral T cell infiltration. Many studies have shown increased T cells in BRAF-mutated melanomas following treatment with MAPK pathway inhibitors; however, this increase is lost as therapy progresses. MAPK pathway inhibitors can also protect CD8 effector T cells from death through chronic T-cell receptor stimulation. As noted above, MEK inhibitors exert their immune-stimulatory effects by increasing melanocyte-derived antigen expression, increasing $\mathrm{T}$ cell infiltration, and reducing the interaction between tumor cells and M2-like macrophages. This increase in tumor antigen levels may augment antitumor T-cell responses [15]. However, MEK inhibitors may have adverse effects on naive $\mathrm{T}$ cell proliferation, viability, and interferon gamma secretion.

While MAPK inhibitors can induce temporary responses, many of these are not durable. Melanoma patients carrying a BRAF mutation have been shown to exhibit some short-term benefits from targeted therapies, such as MAPK inhibitors. Conversely, immunotherapy (such as immune checkpoint blockades) has been shown to induce longer-term responses in approximately one-third of patients [14]. Recent studies suggested that short-term inhibition of both BRAF and MEK in combination with anti-PD-1/L1 antibodies could enhance tumor immune infiltration, and improve tumor control in a CD8 T cells-dependent manner. Combination therapy with MAPK inhibitors and immune checkpoint inhibitors may overcome some of the limitations associated with the monotherapies.

Clinical trials are currently ongoing to investigate combinations of immune checkpoint blockades (particularly anti-PD-1/L1 therapies) with BRAF and/or MEK inhibitors. A long-term study is needed to determine the potential toxicity of each single agent when used in combination therapy. One phase I study reported preliminary clinical activity and a tolerable safety profile for an anti-PD-L1 antibody in combination with dabrafenib (BRAF inhibitor) and trametinib (MEK inhibitor) in BRAF-mutated melanoma as well as in BRAF wild-type melanoma [37]. An ongoing phase II study is currently investigating the efficacy of pembrolizumab (anti-PD-1 therapy) in combination with intermittent or continuous administration of BRAF and MEK inhibitors (dabrafenib and trametinib) in patients with advanced melanoma (NCT02625337) [38,39]. 
Optimizing the sequence in which checkpoint inhibitors and targeted therapies are given (sequential rather than in combination) may also have potential benefits, such as reduced toxicity and reduced costs associated with concurrent approaches used over long periods. In a phase II trial (CA184-240/NCT01673854), ipilimumab was introduced after 6 weeks of vemurafenib therapy, preventing the liver toxicity observed when the treatments were used simultaneously [38]. In that trial, sequential treatment was tolerable, and resulted in a median PFS of 4.4 months and an overall response rate (ORR) of 30\% following initial vemurafenib and ipilimumab treatment [38]. Regardless of whether BRAF and/or MAPK inhibitors are administered sequentially or in combination with an immune checkpoint inhibitor, treatment with both agents leads to more durable responses in patients with BRAF-mutated melanoma [38]. This is likely due to the compensatory and synergistic relationship between the two types of therapies. Approaches to integrate targeted therapies with immunotherapies have helped to overcome the limitations of each individual regimen and strengthen the responses to monotherapy. Here, we review ongoing clinical trials in patients with melanoma, NSCLC, colon cancer, pancreatic cancer, and thyroid cancer. We also added adverse effects of the combination therapies of melanoma. Since clinical trials of other types of cancer have not been completed or terminated, their adverse side effects have not been available yet.

\subsection{Melanoma}

The primary treatment option for patients with early-stage melanoma is surgery; however, surgery is not the best solution for patients with advanced melanoma due to the high rate of metastasis. Generally, conventional chemotherapy is used for patients with late-stage melanoma, but the response rate is very poor, at approximately $5 \%[40,41]$. However, following the recent development of targeted therapies and immunotherapies, substantial improvements have been made in the prognosis of melanoma. The BRAF V600 mutation leads to the constitutive activation of the MAPK pathway in more than $50 \%$ of patients with melanoma [42]. Following approval of the BRAF inhibitor vemurafenib by the FDA in 2011 for patients with advanced melanoma, PFS and OS rates have improved significantly [11]. In 2013, another BRAF inhibitor, dabrafenib, was approved by the FDA, and was shown to improve function compared with vemurafenib [43]. These inhibitors were found to result in remarkable clinical responses in the short term; however, long-term responses are uncommon due to acquired resistance [44].

Since MAPK pathways are reactivated by the BRAF mutation, MEK (MAPK Kinase) inhibitors, including trametinib, have been developed. Trametinib inhibits MEK1/2 and was the first MEK inhibitor to be approved by the FDA for the treatment of patients with advanced melanoma [45]. The combination of encorafenib (a BRAF inhibitor) and binimetinib (a MEK inhibitor) was recently approved by the FDA for the treatment of patients with advanced melanoma. Patients with BRAF-mutated melanoma have shown improved PFS and OS following combination treatment with these MAPK pathway inhibitors [46]; however, decreased clinical responses have been reported in patients following several months of treatment [47]. Ongoing clinical trials investigating the treatment of melanoma are shown in Table 5 [38]. 
Table 5. Clinical trials of therapies targeting the MAPK pathway and immunotherapy in patients with melanoma.

\begin{tabular}{|c|c|c|c|c|c|c|}
\hline $\begin{array}{l}\text { National Clinical } \\
\text { Trial (NCT) Number }\end{array}$ & Title & Status & Conditions & Interventions & Phase & Start Date \\
\hline $\begin{array}{c}\text { NCT } \\
01400451\end{array}$ & $\begin{array}{c}\text { Ph I Ipilimumab } \\
\text { Vemurafenib Combo in } \\
\text { Patients with v-Raf Murine } \\
\text { Sarcoma Viral Oncogene } \\
\text { Homolog B1 (BRAF) }\end{array}$ & $\begin{array}{c}\text { Terminated } \\
\text { (unexpected grade 2/3 } \\
\text { hepatotoxicity) }\end{array}$ & • Melanoma & $\begin{array}{l}\text { - Drug: Ipilimumab } \\
\text { (BMS-734016) } \\
\text { - Drug: Vemurafenib }\end{array}$ & Phase 1 & November 2011 \\
\hline $\begin{array}{c}\text { NCT } \\
01673854\end{array}$ & $\begin{array}{l}\text { Phase II Safety Study of } \\
\text { Vemurafenib Followed by } \\
\text { Ipilimumab in Subjects with } \\
\text { V600 BRAF Mutated } \\
\text { Advanced } \\
\text { Melanoma }\end{array}$ & $\begin{array}{l}\text { Completed } \\
\text { (no severe } \\
\text { hepatotoxicity, but } \\
\text { reported a grade } 3 / 4 \\
\text { skin adverse event) }\end{array}$ & • Melanoma & $\begin{array}{l}\text { - Drug: Ipilimumab } \\
\text { - Biological: Vemurafenib }\end{array}$ & Phase 2 & 13 September 2012 \\
\hline $\begin{array}{c}\text { NCT } \\
03554083\end{array}$ & $\begin{array}{l}\text { Neoadjuvant Combination } \\
\text { Targeted and } \\
\text { Immunotherapy } \\
\text { for Patients with High-Risk } \\
\text { Stage III Melanoma }\end{array}$ & Recruiting & $\begin{array}{l}\text { - Clinical stage } \\
\text { iii cutaneous } \\
\text { melanoma ajcc v8 } \\
\text { - Pathologic Stage } \\
\text { III Cutaneous } \\
\text { Melanoma AJCC v8 } \\
\text { - Pathologic Stage } \\
\text { IIIA Cutaneous } \\
\text { Melanoma AJCC v8 } \\
\text { - Pathologic Stage } \\
\text { IIIB Cutaneous } \\
\text { Melanoma AJCC v8 } \\
\text { - Pathologic Stage } \\
\text { IIIC Cutaneous } \\
\text { Melanoma AJCC v8 } \\
\text { - Pathologic Stage } \\
\text { IIID Cutaneous } \\
\text { Melanoma AJCC v8 }\end{array}$ & $\begin{array}{l}\text { - Drug: Atezolizumab } \\
\text { - Drug: Cobimetinib } \\
\text { - Drug: Vemurafenib }\end{array}$ & Phase 2 & 22 June 2018 \\
\hline $\begin{array}{c}\text { NCT } \\
03235245\end{array}$ & $\begin{array}{l}\text { Immunotherapy with } \\
\text { Ipilimumab and Nivolumab } \\
\text { Preceded or Not by a } \\
\text { Targeted Therapy with } \\
\text { Encorafenib and Binimetinib }\end{array}$ & Recruiting & $\begin{array}{l}\text { - Unresectable Stage } \\
\text { III Melanoma } \\
\text { - Stage IV Melanoma }\end{array}$ & $\begin{array}{l}\text { - Drug: Nivolumab + } \\
\text { Ipilimumab } \\
\text { • Drug: Encorafenib+ } \\
\text { Binimetinib }\end{array}$ & Phase 2 & 30 October 2018 \\
\hline
\end{tabular}


Table 5. Cont

\begin{tabular}{|c|c|c|c|c|c|c|}
\hline $\begin{array}{l}\text { National Clinical } \\
\text { Trial (NCT) Number }\end{array}$ & Title & Status & Conditions & Interventions & Phase & Start Date \\
\hline $\begin{array}{c}\text { NCT } \\
02967692\end{array}$ & $\begin{array}{c}\text { A Study of the Anti-PD1 } \\
\text { Antibody PDR001, in } \\
\text { Combination with } \\
\text { Dabrafenib } \\
\text { and Trametinib in Advanced } \\
\text { Melanoma }\end{array}$ & Recruiting & • Melanoma & $\begin{array}{l}\text { - Biological: } \\
\text { Spartalizumab (PDR001) } \\
\text { - Other: Placebo } \\
\text { - Drug: Dabrafenib } \\
\text { - Drug: Trametinib }\end{array}$ & Phase 3 & 17 February 2017 \\
\hline $\begin{array}{c}\text { NCT } \\
02902042\end{array}$ & $\begin{array}{c}\text { Encorafenib + Binimetinib + } \\
\text { Pembrolizumab in Patients } \\
\text { with Unresectable or } \\
\text { Metastatic } \\
\text { BRAF V600 Mutant } \\
\text { Melanoma }\end{array}$ & Recruiting & $\begin{array}{l}\text { - Malignant } \\
\text { Melanoma }\end{array}$ & $\begin{array}{l}\text { - Drug: Encorafenib } \\
\text { - Drug: Binimetinib } \\
\text { - Drug: Pembrolizumab } \\
\text { - Drug: } \\
\text { Pembrolizumabalone }\end{array}$ & $\begin{array}{l}\text { - Phase } 1 \\
\text { - Phase } 2\end{array}$ & 24 April 2018 \\
\hline $\begin{array}{c}\text { NCT } \\
02858921\end{array}$ & $\begin{array}{c}\text { Neoadjuvant Dabrafenib, } \\
\text { Trametinib and/or } \\
\text { Pembrolizumab in BRAF } \\
\text { Mutant } \\
\text { Resectable Stage III } \\
\text { Melanoma }\end{array}$ & Recruiting & - Melanoma & $\begin{array}{l}\text { - Melanoma } \\
\text { - Drug: Dabrafenib } \\
\text { - Drug: Trametinib } \\
\text { - Drug: Pembrolizumab }\end{array}$ & Phase 2 & 8 November 2017 \\
\hline
\end{tabular}


To enhance the clinical response to therapies targeting the MAPK pathway, clinical trials are investigating regimens that incorporate both targeted therapies and immunotherapies, specifically immune checkpoint inhibitors. For example, NCT01400451 is investigating the efficacy and safety of vemurafenib (BRAF inhibitor) in combination with ipilimumab (CTLA-4-Ab) for the treatment of patients with metastatic melanoma expressing an activated mutant form of BRAF V600E [38]. NCT01400451 was closed to enrollment and Phase II was not initiated, because the drug combination was not fully tolerated, and the highest tolerable dosage was not established [38]. The adverse event was unexpected grade 2/3 hepatotoxicity [38]. NCT01673854 is investigating the safety of vemurafenib, administered at $960 \mathrm{mg}$ for 6 weeks along with ipilimumab in a sequential manner, to BRAF V600-mutated melanoma patients [38]. No severe hepatotoxicity was observed, but a grade $3 / 4$ skin adverse event has been reported [38]. NCT03554083 is studying the effect of combined treatment with cobimetinib (MEK inhibitor) and atezolizumab (PD-L1-Ab), and with vemurafenib (BRAF inhibitor), cobimetinib, and atezolizumab for the treatment of patients with high-risk stage III melanoma [38]. NCT03235245 is a phase II study evaluating the effect of combination targeted therapy (encorafenib and binimetinib) followed by combination immunotherapy (ipilimumab and nivolumab) compared with combination immunotherapy alone (ipilimumab and nivolumab) in patients with BRAF V600-mutated unresectable or metastatic melanoma [38]. NCT02967692 is a phase III study evaluating the safety and efficacy of the combination spartalizumab (anti-PD-1 antibody), dabrafenib (BRAF inhibitor), and trametinib (MEK inhibitor) in patients with unresectable or metastatic BRAF V600-mutated melanoma [38]. Adverse events of any grade included pyrexia $(n=14,61 \%)$, arthralgia, fatigue, rash, and vomiting ( $n=4$ each, 17\%) [38]. NCT02902042 is a phase I/II study investigating the efficacy and safety of encorafenib (BRAF inhibitor) combined with binimetinib (MEK inhibitor) and pembrolizumab (anti-PD-1 antibody) in patients with BRAF V600-mutated unresectable or metastatic melanoma [38]. NCT02858921 is a phase II trial designed to determine the optimal combination of drugs (dabrafenib, trametinib, and/or pembrolizumab) to reduce tumor size prior to surgery for patients with BRAF V600-mutated, resectable stage IIIB/C melanoma [38]. That study is also examining drug combinations to prevent the recurrence of melanoma after resection.

\subsection{Non-Small-Cell Lung Cancer (NSCLC)}

Lung cancer occurs at a high incidence and is associated with mortality in both males and females. Patients with early-stage (stage I, II, and IIIA) resectable NSCLC generally undergo surgery to remove the tumor [48]. However, about $80 \%$ of lung cancers are diagnosed as advanced-stage NSCLC, for which surgical resection is not a suitable strategy. In addition, tumor recurrence can occur within a few years of surgery [49]. Therefore, chemotherapy is used the first-line treatment for patients with late-stage NSCLC patients [48].

Increased knowledge on the correlation between the immune system and lung cancer has led to the development of immunotherapies for the treatment of patients with NSCLC. The success of anti-PD-1/PD-L1 antibodies has been reported in multiple clinical trials, with significant responses and low toxicities observed in patients with NSCLC [50]. Chemotherapy has been shown to have minimal effects in patients with high PD-L1 levels and low expression of causative mutations. Chemotherapy was found to enhance the amount of PD-L1 on tumor cells, as well as the number of TILs [51]; hence, immune checkpoint inhibitors combined with chemotherapy have shown promising clinical results $[52,53]$.

Over the past decades, there has been substantial progress in the treatment of patients with NSCLC due to the development of therapies targeting mutations in the epidermal growth factor receptor (EGFR) and anaplastic lymphoma kinase (ALK) translocations [54]. Most EGFR mutations comprise exon 19 deletions and exon 21 L858R mutations; these lead to the constitutive activation of downstream signaling events, including MAPK, phosphoinositide 3-kinase (PI3K), and signal transducer and activator of transcription (STAT) [55].

Ongoing clinical trials in NSCLC combining MAPK inhibitors and immune checkpoint inhibitors are reviewed in Table 6 [38]. NCT03991819 is a phase I/lb study investigating the efficacy, safety, and best dose of binimetinib (MEK inhibitor) in combination with pembrolizumab (anti-PD-1 antibody) 
for the treatment of patients with advanced NSCLC [38]. The phase I part of study NCT03991819 comprises a dose de-escalation to determine the maximum dose of binimetinib that can be administered with pembrolizumab without having significant adverse events [38]. The efficacy, safety, tolerability, and antitumor activity of the dose determined in the phase I part will be evaluated in the phase $\mathrm{Ib}$ part [38]. NCT03600701 is a phase II trial assessing the effect of atezolizumab (anti-PD-L1 antibody) and cobimetinib (MEK inhibitor) for the treatment of patients with metastatic, recurrent, or refractory NSCLC [38]. NCT03581487 is a phase I/II trial analyzing the best dose of selumetinib (MEK inhibitor) in combination with durvalumab (anti-PD-L1 antibody) and tremelimumab (CTLA-4-Ab) for the treatment of patients with stage IV or recurrent NSCLC [38]. NCT03299088 is a phase Ib study investigating the safety of pembrolizumab (anti-PD-1 antibody) and trametinib (MEK inhibitor) for the treatment of patients with metastatic KRAS-mutated NSCLC [38]. NCT03225664 is a phase Ib/II trial assessing the safety and best dose of trametinib (MEK inhibitor) in combination with pembrolizumab (anti-PD-1 antibody) for the treatment of patients with metastatic, recurrent, locally advanced, and unresectable NSCLC [38]. 
Table 6. Clinical trials of therapies targeting the MAPK pathway and immunotherapies in patients with NSCLC.

\begin{tabular}{|c|c|c|c|c|c|c|}
\hline $\begin{array}{l}\text { National Clinical } \\
\text { Trial (NCT) Number }\end{array}$ & Title & Status & Conditions & Interventions & Phase & Start Date \\
\hline $\begin{array}{c}\text { NCT } \\
03991819\end{array}$ & $\begin{array}{l}\text { Study of Binimetinib } \\
\text { in Combination with } \\
\text { Pembrolizumab in Advanced } \\
\text { Non-Small-Cell Lung Cancer }\end{array}$ & Recruiting & $\begin{array}{l}\text { - Non-Small-Cell } \\
\text { Carcinoma }\end{array}$ & $\begin{array}{l}\text { - Drug: Binimetinib } \\
\text { - Drug: } \\
\text { Pembrolizumab }\end{array}$ & • Phase 1 & 20 September 2019 \\
\hline $\begin{array}{c}\text { NCT } \\
03600701\end{array}$ & $\begin{array}{c}\text { Atezolizumab and Cobimetinib } \\
\text { in Treating Patients with } \\
\text { Metastatic, Recurrent, or } \\
\text { Refractory Non-Small-Cell } \\
\text { Lung } \\
\text { Cancer }\end{array}$ & Recruiting & $\begin{array}{l}\text { - Recurrent Lung } \\
\text { Non-Small-Cell } \\
\text { Carcinoma } \\
\text { - Refractory Lung } \\
\text { Non-Small-Cell } \\
\text { Carcinoma } \\
\text { - Stage IV Lung Non- } \\
\text { Small-Cell Cancer AJCC v7 }\end{array}$ & $\begin{array}{l}\text { - Drug: Atezolizumab } \\
\text { - Drug: Cobimetinib }\end{array}$ & Phase 2 & 20 July 2018 \\
\hline $\begin{array}{c}\text { NCT } \\
03581487\end{array}$ & $\begin{array}{c}\text { Durvalumab, Tremelimumab, } \\
\text { and Selumetinib in Treating } \\
\text { Participants with Recurrent or } \\
\text { Stage IV Non-Small-Cell Lung } \\
\text { Cancer }\end{array}$ & Recruiting & $\begin{array}{l}\text { - Recurrent Lung } \\
\text { Non-Small-Cell Carcinoma } \\
\text { - Stage IV Lung } \\
\text { Cancer AJCC v8 } \\
\text { - Stage IVA Lung } \\
\text { Cancer AJCC v8 } \\
\text { - Stage IVB Lung } \\
\text { Cancer AJCC v8 }\end{array}$ & $\begin{array}{l}\text { - Biological: } \\
\text { Durvalumab } \\
\text { - Drug: Selumetinib } \\
\text { - Biological:Tremelimumab }\end{array}$ & $\begin{array}{l}\text { - Phase } 1 \\
\text { - Phase } 2\end{array}$ & 1 April 2019 \\
\hline $\begin{array}{c}\text { NCT } \\
03299088\end{array}$ & $\begin{array}{l}\text { Pembrolizumab and } \\
\text { Trametinib } \\
\text { in Treating Patients with Stage } \\
\text { IV Non-Small-Cell Lung } \\
\text { Cancer } \\
\text { and KRAS Gene Mutations }\end{array}$ & Recruiting & $\begin{array}{l}\text { - KRAS Gene Mutation } \\
\text { - Metastatic Non- } \\
\text { Squamous Non- } \\
\text { Small Cell Lung Carcinoma } \\
\text { - Recurrent Non- } \\
\text { Squamous Non- } \\
\text { Small Cell Lung } \\
\text { Carcinoma } \\
\text { - Stage IV Non-Small-Cell } \\
\text { Lung Cancer AJCC v7 }\end{array}$ & $\begin{array}{l}\text { - Biological: } \\
\text { Pembrolizumab } \\
\text { - Drug: Trametinib }\end{array}$ & Phase 1 & 26 June 2018 \\
\hline
\end{tabular}


Table 6. Cont.

\begin{tabular}{|c|c|c|c|c|c|c|}
\hline $\begin{array}{l}\text { National Clinical } \\
\text { Trial (NCT) Number }\end{array}$ & Title & Status & Conditions & Interventions & Phase & Start Date \\
\hline $\begin{array}{c}\text { NCT } \\
03225664\end{array}$ & $\begin{array}{c}\text { Trametinib and } \\
\text { Pembrolizumab } \\
\text { in Treating Patients with } \\
\text { Recurrent Non-Small-Cell } \\
\text { Lung } \\
\text { Cancer That Is Metastatic, } \\
\text { Unresectable, or Locally } \\
\text { Advanced }\end{array}$ & Recruiting & $\begin{array}{l}\text { - Metastatic Lung } \\
\text { Non-Small-Cell Carcinoma } \\
\text { - Recurrent Lung } \\
\text { Non-Small-Cell Carcinoma } \\
\text { - Stage III Lung } \\
\text { Cancer AJCC v8 } \\
\text { - Stage IIIA Lung } \\
\text { Cancer AJCC v8 } \\
\text { - Stage IIIB Lung } \\
\text { Cancer AJCC v8 } \\
\text { - Stage IIIC Lung } \\
\text { Cancer AJCC v8 } \\
\text { - Stage IV Lung } \\
\text { Cancer AJCC v8 } \\
\text { - Stage IVA Lung } \\
\text { Cancer AJCC v8 } \\
\text { - Stage IVB Lung } \\
\text { Cancer AJCC v8 } \\
\text { - Unresectable Lung } \\
\text { Non-Small-Cell Carcinoma }\end{array}$ & $\begin{array}{l}\text { - Biological: } \\
\text { Pembrolizumab } \\
\text { - Other: } \\
\text { Pharmacokinetic } \\
\text { Study } \\
\text { - Drug: Trametinib }\end{array}$ & $\begin{array}{l}\text { - Phase } 1 \\
\text { - Phase } 2\end{array}$ & 3 February 2018 \\
\hline
\end{tabular}




\subsection{Colorectal Cancer (CRC)}

CRC is the third most common cancer worldwide [56], and OS for patients with metastatic CRC remains low. Standard treatment of CRC includes surgery followed by adjuvant chemotherapy $[57,58]$. Common mutations of CRC, including KRAS, p53, SMAD4, and BRAF play significant roles in CRC metastasis [57]. Clinical trials investigating MAPK inhibitors in patients with CRC are summarized in Table 7 [38]. In trial NCT01436656, a $300 \mathrm{mg}$ dosage of encorafenib once daily was declared the recommended phase II dose (RP2D) [59]. The most common adverse events were nausea, myalgia, and palmar-plantar erythrodysesthesia [59]. In BRAF inhibitor-naive patients, the ORR and median PFS (mPFS) were 60\% and 12.4 months, respectively [59]. In BRAF inhibitor-pretreated patients, the ORR and mPFS were 22\% and 1.9 months, respectively [59]. In trial NCT00959127, the maximum tolerated dose (MTD) was $60 \mathrm{mg}$ twice daily with a subsequent decrease to $45 \mathrm{mg}$ twice daily due to the frequency of treatment-related ocular toxicities [60]. Common adverse events were mostly grade $1 / 2$ rash, nausea, vomiting, diarrhea, peripheral edema, and fatigue [60]. Target inhibition was observed in serum and skin biopsy samples [60].

Although immune checkpoint inhibitors, including anti-PD-1 antibodies (nivolumab, pembrolizumab), anti-PD-L1 antibodies (atezolizumab, durvalumab, avelumab), and anti-CTLA-4 antibodies (ipilimumab, tremelimumab), have demonstrated efficacy in many cancers, no favorable clinical responses have been reported in patients with CRC [58]. However, immune checkpoint inhibitors may have a more favorable effect when used in combination with MAPK pathway-targeted therapy. Due to the low efficacy observed with immune checkpoint inhibitors in patients with $\mathrm{CRC}$, combination strategies including targeted therapies and chemotherapy have been developed to enhance the immune response of these patients. Ongoing clinical trials investigating the combination treatment of CRC with an immune checkpoint inhibitor and MAPK-targeted therapy are presented in Table 8 [38]. NCT04044430 is a phase I/II trial investigating the effects of encorafenib (BRAF inhibitor), binimetinib (MEK inhibitor), and nivolumab (anti-PD-1 antibody) in patients with microsatellite stable (MSS), BRAF V600E-mutated metastatic CRC [38]. Trial NCT03428126 is investigating the efficacy and safety of durvalumab (anti-PD-L1 antibody) and trametinib (MEK inhibitor) in patients with MSS CRC. Durvalumab is an FDA-approved antibody used for the treatment of patients with previously treated advanced bladder cancer. Trametinib is an FDA-approved MEK inhibitor targeting advanced melanoma bearing BRAF V600E or V600K mutation with dabrafenib (BRAF inhibitor) [38]. NCT03374254 is a phase Ib study examining the efficacy and safety of combined pembrolizumab (anti-PD-1 antibody) and binimetinib (MEK inhibitor), compared with combined pembrolizumab and chemotherapy, with or without binimetinib, in patients with metastatic CRC [38]. NCT03374254 is a multi-cohort study aiming to establish the recommended phase 2 dose (RP2D) of the following five combinations (cohorts): cohort $\mathrm{A}$, pembrolizumab and binimetinib; cohort $\mathrm{B}$, pembrolizumab and mFOLFOX7 (oxaliplatin $85 \mathrm{mg} / \mathrm{m}^{2}$, leucovorin (calcium folinate) $400 \mathrm{mg} / \mathrm{m}^{2}$, fluorouracil (5-FU) $2400 \mathrm{mg} / \mathrm{m}^{2}$ ); cohort C, pembrolizumab with mFOLFOX7 and binimetinib; cohort D, pembrolizumab, FOLFIRI (irinotecan $180 \mathrm{mg} / \mathrm{m}^{2}$, leucovorin (calcium folinate) $400 \mathrm{mg} / \mathrm{m}^{2}, 5-\mathrm{FU} 2400 \mathrm{mg} / \mathrm{m}^{2}$ over 46-48 h); and cohort E, pembrolizumab plus FOLFIRI and binimetinib [38]. 
Table 7. Clinical trials of therapies targeting the MAPK pathway in patients with colorectal cancer.

\begin{tabular}{|c|c|c|c|c|c|c|}
\hline $\begin{array}{l}\text { National Clinical } \\
\text { Trial (NCT) Number }\end{array}$ & Title & Status & Conditions & Interventions & Phase & Start Date \\
\hline $\begin{array}{c}\text { NCT } \\
01436656\end{array}$ & $\begin{array}{l}\text { A Phase I Study of Oral } \\
\text { LGX818 in Adult Patients } \\
\text { with Advanced or } \\
\text { Metastatic BRAF Mutant } \\
\text { Melanoma }\end{array}$ & Active, not recruiting & $\begin{array}{l}\text { - Melanoma and Metastatic } \\
\text { Colorectal Cancer }\end{array}$ & • Drug: LGX818 & • Phase 1 & September 2011 \\
\hline $\begin{array}{c}\text { NCT } \\
00959127\end{array}$ & $\begin{array}{l}\text { A Study of ARRY-438162 } \\
\text { (MEK162) in Patients } \\
\text { with Advanced Cancer }\end{array}$ & Completed & $\begin{array}{l}\text { - Advanced Solid Tumors } \\
\text { - Advanced or Metastatic } \\
\text { Biliary Cancer } \\
\text { - Metastatic Colorectal Cancer }\end{array}$ & $\begin{array}{l}\text { - Drug: ARRY-438162 } \\
\text { (MEK162), MEK } \\
\text { inhibitor; oral }\end{array}$ & Phase 1 & August 2009 \\
\hline
\end{tabular}


Table 8. Clinical trials investigating therapies targeting the MAPK pathway and immunotherapies in patients with colorectal cancer.

\begin{tabular}{|c|c|c|c|c|c|c|}
\hline $\begin{array}{l}\text { National Clinical } \\
\text { Trial (NCT) Number }\end{array}$ & Title & Status & Conditions & Interventions & Phase & Start Date \\
\hline $\begin{array}{c}\text { NCT } \\
04044430\end{array}$ & $\begin{array}{c}\text { Encorafenib, Binimetinib, } \\
\text { and Nivolumab in Treating } \\
\text { Patients with Microsatellite } \\
\text { Stable BRAFV600E Metastatic } \\
\text { Colorectal Cancer }\end{array}$ & $\begin{array}{l}\text { Not yet } \\
\text { recruiting }\end{array}$ & $\begin{array}{l}\text { - Metastatic Colon } \\
\text { Adenocarcinoma } \\
\text { - Metastatic } \\
\text { Colorectal } \\
\text { Adenocarcinoma } \\
\text { - Metastatic } \\
\text { Microsatellite } \\
\text { Stable Colorectal } \\
\text { Carcinoma } \\
\text { - Metastatic Rectal } \\
\text { Adenocarcinoma } \\
\text { - Stage III Colon } \\
\text { Cancer } \\
\text { - Stage III Colorectal } \\
\text { Cancer } \\
\text { - Stage III Rectal } \\
\text { Cancer } \\
\text { - Stage IIIA Colon } \\
\text { Cancer } \\
\text { - Stage IIIA } \\
\text { Colorectal Cancer } \\
\text { - Stage IIIA Rectal } \\
\text { Cancer } \\
\text { - and } 18 \text { more }\end{array}$ & $\begin{array}{l}\text { - Drug: Binimetinib } \\
\text { - Drug: Encorafenib } \\
\text { - Biological: } \\
\text { Nivolumab } \\
\text { - Other: } \\
\text { Questionnaire } \\
\text { Administration }\end{array}$ & $\begin{array}{l}\text { - Phase } 1 \\
\text { - Phase } 2\end{array}$ & 1 December 2019 \\
\hline NCT 03428126 & $\begin{array}{c}\text { Study of Durvalumab } \\
\text { (MEDI4736) (Anti-PD-L1) and } \\
\text { Trametinib (MEKi) in MSS Metastatic } \\
\text { Colon Cancer }\end{array}$ & $\begin{array}{l}\text { Enrolling by } \\
\text { invitation }\end{array}$ & $\begin{array}{l}\text { - Malignant } \\
\text { Neoplasms of } \\
\text { Digestive Organs } \\
\text { - Colorectal Cancer } \\
\text { - Colon Cancer }\end{array}$ & $\begin{array}{l}\text { - Drug: Durvalumab } \\
\text { - Drug: Trametinib }\end{array}$ & Phase 2 & 21 March 2018 \\
\hline NCT 03374254 & $\begin{array}{c}\text { Safety and Efficacy of } \\
\text { Pembrolizumab (MK-3475) } \\
\text { Plus Binimetinib Alone } \\
\text { or Pembrolizumab Plus } \\
\text { Chemotherapy with or without } \\
\text { Binimetinib in Metastatic Colorectal } \\
\text { Cancer (mCRC) } \\
\text { Participants (MK-3475-651) }\end{array}$ & Recruiting & $\begin{array}{l}\text { - Metastatic } \\
\text { Colorectal Cancer }\end{array}$ & $\begin{array}{l}\text { - Biological: } \\
\text { Pembrolizumab } \\
\text { - Drug: Binimetinib } \\
\text { - Drug: Oxaliplatin } \\
\text { - Drug: Leucovorin } \\
\text { - Drug: 5-Fluorouracil } \\
\text { [5-FU] } \\
\text { - Drug: Irinotecan }\end{array}$ & Phase 1 & 16 February 2018 \\
\hline
\end{tabular}




\subsection{Pancreatic Cancer}

Pancreatic ductal adenocarcinoma (PDAC) is one of the most lethal cancers worldwide, and the mortality rate is almost equivalent to the occurrence rate [61]. At the time of diagnosis, it is usually too late for surgical resection, since most patients already have advanced and metastatic disease. The 5-year survival rate for patients with PDAC is less than 10\%, primarily due to the delayed diagnosis [61]. The driver mutations of PDAC include high rate of activated KRAS mutations, and inactivated form of mutations of TP53, SMAD4/DPC4, and P16/CDKN2A [62]. Other characteristics of PDAC include a lack of specific markers, a low response to chemotherapy, and a very low response rate to targeted therapies against MEK, PI3K, and EGFR [63-65]. This is related to the innate or acquired resistance of pancreatic cancer cells to these therapies $[66,67]$.

The tumor microenvironment (TME) of PDAC includes a highly complex structure, in which a large proportion of cancer cells and the extracellular matrix is resistant to permeation by chemotherapeutic drugs [68]. The lack of successful clinical results in patients with PDAC is possibly due to immune suppression and escape [69]. While immune checkpoint inhibitors have demonstrated significant clinical benefits in various types of cancers, including melanoma, lung, renal, and hematological cancers [70-74], their efficacy in patients with PDAC is poor, with no clinical benefits observed [75].

Despite this resistance of PDAC to several therapeutic strategies, a phase Ib/II clinical trial (NCT03193190) investigating combination therapy with cobimetinib (MEK inhibitor) and atezolizumab (anti-PD-L1 antibody) in patients with metastatic PDAC is now underway; however, the results are still pending (Table 9) [38]. This study includes two patient cohorts: cohort 1, patients without any prior systemic therapy; and cohort 2, patients with one line of prior systemic therapy [38]. Another clinical trial (NCT03637491) investigating avelumab (anti-PD-L1 antibody) combined with binimetinib (MEK inhibitor) in patients with PDAC is also underway (Table 9) [38]. NCT03637491 is a phase 1b/2 study testing the effects of avelumab (anti-PD-L1 antibody), binimetinib (MEK inhibitor), and talazoparib (poly ADP ribose polymerase (PARP) inhibitor) in combination as two or three drugs for patients with metastatic PDAC and locally advanced or metastatic KRAS- or NRAS-mutated solid tumors [38]. The phase Ib part will evaluate the optimal combination of drugs, and their doses, and phase II will study the safety and efficacy of these drugs in terms of side effects and tumor growth [38]. 
Table 9. Clinical trials of therapies targeting the MAPK pathway and immunotherapies in patients with pancreatic cancer.

\begin{tabular}{|c|c|c|c|c|c|c|}
\hline $\begin{array}{l}\text { National Clinical } \\
\text { Trial (NCT) Number }\end{array}$ & Title & Status & Conditions & Interventions & Phase & Start Date \\
\hline $\begin{array}{c}\text { NCT } \\
03193190\end{array}$ & $\begin{array}{c}\text { A Study of Multiple } \\
\text { Immunotherapy-Based } \\
\text { Treatment Combinations } \\
\text { in Participants with } \\
\text { Metastatic Pancreatic } \\
\text { Ductal Adenocarcinoma } \\
\text { (Morpheus Pancreatic } \\
\text { Cancer) }\end{array}$ & Recruiting & $\begin{array}{l}\text { - Pancreatic } \\
\text { Adenocarcinoma }\end{array}$ & $\begin{array}{l}\text { - Drug: NabPaclitaxel } \\
\text { - Drug: Gemcitabine } \\
\text { - Drug: Oxaliplatin } \\
\text { - Drug: Leucovorin } \\
\text { - Drug: Fluorouracil } \\
\text { - Drug: Atezolizumab } \\
\text { - Drug: Cobimetinib } \\
\text { - Drug: PEGPH20 } \\
\text { - Drug: BL-8040 } \\
\text { - Drug: Selicrelumab } \\
\text { - and } 3 \text { more }\end{array}$ & $\begin{array}{l}\text { - Phase } 1 \\
\text { - Phase } 2\end{array}$ & 5 July 2017 \\
\hline $\begin{array}{c}\text { NCT } \\
03637491\end{array}$ & $\begin{array}{l}\text { A Study of Avelumab, } \\
\text { Binimetinib and } \\
\text { Talazoparib in Patients } \\
\text { with Locally Advanced or } \\
\text { Metastatic RAS-mutant } \\
\text { Solid Tumors }\end{array}$ & Recruiting & - Pancreatic Cancer & $\begin{array}{l}\text { - Drug: Avelumab } \\
\text { - Drug: Binimetinib } \\
\text { - Drug: Talazoparib }\end{array}$ & Phase 2 & 15 August 2018 \\
\hline
\end{tabular}




\subsection{Thyroid Cancer}

Thyroid cancer is the most common endocrine tumors [76]. Standard therapy for patients with thyroid cancer includes surgery and treatment with radioactive iodine $[77,78]$. The major driver mutations of thyroid cancer include $B R A F$ and $R A S$ mutations, and transfusion/papillary thyroid carcinoma (RET/PTC) rearrangements [79].

Although use of a targeted therapy against the MAPK pathway generated a favorable clinical response in patients with thyroid cancer, the OS rate remains controversial [80]. This may be due to the toxicity of the MAPK inhibitor and the resistance of the tumor microenvironment. Therefore, new strategies are required to overcome these limitations.

Reports have shown that combination therapy with a MAPK pathway-targeted inhibitor and immunotherapy may induce favorable responses in patients with thyroid cancer based on the immunomodulatory effect of MAPK inhibitors. NCT04061980 is a phase II clinical trial combining a MAPK inhibitor and a PD-1 inhibitor [38]; this study aims to assess the efficacy and safety of encorafenib (BRAF inhibitor) and binimetinib (MEK inhibitor) with or without nivolumab (anti-PD-1 antibody) in patients with BRAF V600-mutated metastatic and refractory thyroid cancer not responsive to radioiodine treatment (Table 10) [38]. Encorafenib and binimetinib have been reported to inhibit the tumor growth, and nivolumab is an anti-PD1 monoclonal antibody that boosts the immune system to suppress tumor metastasis and growth [38]. Clinical trials investigating treatments for various forms of cancer have demonstrated the feasibility of combination therapy using MAPK inhibitors and checkpoint blockers, and the ability of this approach to overcome the limitations associated with the respective monotherapy. 
Table 10. Clinical trials investigating combined MAPK pathway-targeted therapy and immunotherapy in patients with thyroid cancer.

\begin{tabular}{|c|c|c|c|c|c|c|}
\hline $\begin{array}{l}\text { National Clinical } \\
\text { Trial (NCT) Number }\end{array}$ & Title & Status & Conditions & Interventions & Phase & Start Date \\
\hline $\begin{array}{c}\text { NCT } \\
04061980\end{array}$ & $\begin{array}{c}\text { Encorafenib and } \\
\text { Binimetinib with or } \\
\text { without Nivolumab } \\
\text { in Treating Patients } \\
\text { with Metastatic } \\
\text { Radioiodine } \\
\text { Refractory BRAF } \\
\text { V600 Mutant Thyroid } \\
\text { Cancer }\end{array}$ & Not yet recruiting & $\begin{array}{l}\text { - BRAF NP_004324.2:p.V600M • } \\
\text { BRAF V600E Mutation Present } \\
\text { - Metastatic Thyroid Gland } \\
\text { Carcinoma } \\
\text { - Refractory Thyroid Gland } \\
\text { Carcinoma } \\
\text { - Stage IV Differentiated Thyroid } \\
\text { Gland Carcinoma AJCC v8 } \\
\text { - Stage IVA Differentiated Thyroid } \\
\text { Gland Carcinoma AJCC v8 } \\
\text { - Stage IVB Differentiated Thyroid } \\
\text { Gland Carcinoma AJCC v8 }\end{array}$ & $\begin{array}{l}\text { - Drug: Binimetinib } \\
\text { - Drug: Encorafenib } \\
\text { - Biological: Nivolumab }\end{array}$ & Phase 2 & 30 August 2019 \\
\hline
\end{tabular}




\section{Conclusions}

Despite the clinical success of cancer immunotherapies, many hurdles and challenges remain. Although targeted therapy is a promising therapeutic option for various types of cancer, the development of acquired resistance remains a significant limitation. Conversely, immunotherapy has been shown to generate long-term effects, but has a low response rate. Increasingly, reports have shown that the effects of targeted therapies are enhanced when used in combination with immune cells and their microenvironments.

Combination therapies target signal transduction cascades required for tumor cell survival and maintenance. While small-molecule inhibitors block intracellular targets, checkpoint inhibitors restore a patient's immune system, enabling the killing of tumor cells as well as metastatic cells and those with acquired mutations. Therefore, it is important to understand the patient's individual tumor mutation burden to select the optimal personalized combination regimen. When discerning a patient's mutation burden, combined treatment with an immune checkpoint inhibitor and a MAPK inhibitor is an effective strategy to overcome resistance to targeted therapies. Further in-depth analyses of the mechanisms of acquired resistance are required to enable the identification of alternatives that restore tumor-specific $\mathrm{T}$ cells and reprogram an immunosuppressive tumor microenvironment.

Author Contributions: Conceptualization: M.H.S., J.K. (Jiyoung Kim) and K.-M.L. Writing-original draft preparation: M.H.S., J.K. (Jiyoung Kim), S.A.L., J.K. (Jeongsoo Kim), and K.-M.L. Writing-review and editing: M.H.S., J.K. (Jiyoung Kim), S.A.L., and K.-M.L. Supervision: K.-M.L. All authors have read and agreed to the final version of the manuscript.

Funding: K.-M.L. was supported by the National Research Foundation of Korea (NRF) grants, NRF-2017R1A2B3004828, NRF-2016M3A9B6948342, NRF-2018M3A9D3079288, and NRF-2018M3A9D3079285. K.-M.L. was also supported by the Korea Health Industry Development Institute (KHIDI-HI14C2640) grant funded by the Korean Government. M.H.S. was supported by the National Research Foundation of Korea (NRF) grant, NRF-2018R1D1A1B07041442 and a Korea University Grant.

Conflicts of Interest: The authors declare no potential conflicts of interests. The funders had no role in the design of the study.

\section{Abbreviations}

$\begin{array}{ll}\text { MAPK } & \text { mitogen-activated protein kinase } \\ \text { NSCLC } & \text { non-small-cell lung carcinoma } \\ \text { MEK } & \text { MAPK/ERK kinase } \\ \text { PD-1 } & \text { programmed death protein 1 } \\ \text { PD-L1 } & \text { programmed death-ligand 1 } \\ \text { PD-L2 } & \text { programmed death-ligand 2 } \\ \text { CTLA-4 } & \text { cytotoxic T cell associated antigen 4 } \\ \text { US FDA } & \text { United States Food and Drug Administration } \\ \text { Tim-3 } & \text { T-cell immunoglobulin and mucin-domain containing-3 } \\ \text { IL-2 } & \text { interleukin 2 } \\ \text { PFS } & \text { progression-free survival } \\ \text { OS } & \text { overall survival } \\ \text { EGFR } & \text { epidermal growth factor receptor } \\ \text { ALK } & \text { anaplastic lymphoma kinase } \\ \text { PI3K } & \text { phosphoinositide 3-kinase } \\ \text { STAT } & \text { signal transducer and activator of transcription } \\ \text { CRC } & \text { colorectal cancer } \\ \text { mCRC } & \text { metastatic colorectal cancer } \\ \text { MSS } & \text { microsatellite stable } \\ \text { mAbs } & \text { monoclonal antibodies } \\ \text { PDAC } & \text { pancreatic ductal adenocarcinoma } \\ \text { PARP } & \text { poly ADP ribose polymerase }\end{array}$


TME tumor microenvironment

RET/PTC rearranged in transfusion/papillary thyroid carcinoma

RP2D recommended phase II dose

ORR overall response rate

mPFS median progression-free survival

MTD maximum tolerated dose

\section{References}

1. Nussinov, R.; Jang, H.; Tsai, C.J.; Cheng, F. Review: Precision medicine and driver mutations: Computational methods, functional assays and conformational principles for interpreting cancer drivers. PLoS Comput. Biol. 2019, 15, e1006658. [CrossRef]

2. National Cancer Institute. Available online: https://www.cancer.gov/ (accessed on 20 December 2019).

3. Yu, C.; Liu, X.; Yang, J.; Zhang, M.; Jin, H.; Ma, X.; Shi, H. Combination of Immunotherapy with Targeted Therapy: Theory and Practice in Metastatic Melanoma. Front. Immunol. 2019, 10, 990. [CrossRef] [PubMed]

4. Yaghoubi, N.; Soltani, A.; Ghazvini, K.; Hassanian, S.M.; Hashemy, S.I. PD-1/ PD-L1 blockade as a novel treatment for colorectal cancer. Biomed. Pharmacother. 2019, 110, 312-318. [CrossRef] [PubMed]

5. Calhoun, E.S.; Jones, J.B.; Ashfaq, R.; Adsay, V.; Baker, S.J.; Valentine, V.; Hempen, P.M.; Hilgers, W.; Yeo, C.J.; Hruban, R.H.; et al. BRAF and FBXW7 (CDC4, FBW7, AGO, SEL10) mutations in distinct subsets of pancreatic cancer: Potential therapeutic targets. Am. J. Pathol. 2003, 163, 1255-1260. [CrossRef]

6. Ebert, P.J.R.; Cheung, J.; Yang, Y.; McNamara, E.; Hong, R.; Moskalenko, M.; Gould, S.E.; Maecker, H.; Irving, B.A.; Kim, J.M.; et al. MAP Kinase Inhibition Promotes T Cell and Anti-tumor Activity in Combination with PD-L1 Checkpoint Blockade. Immunity 2016, 44, 609-621. [CrossRef]

7. Boni, A.; Cogdill, A.P.; Dang, P.; Udayakumar, D.; Njauw, C.N.; Sloss, C.M.; Ferrone, C.R.; Flaherty, K.T.; Lawrence, D.P.; Fisher, D.E.; et al. Selective BRAFV600E inhibition enhances T-cell recognition of melanoma without affecting lymphocyte function. Cancer Res. 2010, 70, 5213-5219. [CrossRef]

8. Cooper, Z.A.; Juneja, V.R.; Sage, P.T.; Frederick, D.T.; Piris, A.; Mitra, D.; Lo, J.A.; Hodi, F.S.; Freeman, G.J.; Bosenberg, M.W.; et al. Response to BRAF inhibition in melanoma is enhanced when combined with immune checkpoint blockade. Cancer Immunol. Res. 2014, 2, 643-654. [CrossRef]

9. Prieto, P.A.; Reuben, A.; Cooper, Z.A.; Wargo, J.A. Targeted Therapies Combined with Immune Checkpoint Therapy. Cancer J. (Sudbury, Mass.) 2016, 22, 138-146. [CrossRef]

10. Amaravadi, R.K.; Schuchter, L.M.; McDermott, D.F.; Kramer, A.; Giles, L.; Gramlich, K.; Carberry, M.; Troxel, A.B.; Letrero, R.; Nathanson, K.L.; et al. Phase II Trial of Temozolomide and Sorafenib in Advanced Melanoma Patients with or without Brain Metastases. Clin. Cancer Res. Off. J. Am. Assoc. Cancer Res. 2009, 15, 7711-7718. [CrossRef]

11. Chapman, P.B.; Hauschild, A.; Robert, C.; Haanen, J.B.; Ascierto, P.; Larkin, J.; Dummer, R.; Garbe, C.; Testori, A.; Maio, M.; et al. Improved survival with vemurafenib in melanoma with BRAF V600E mutation. N. Engl. J. Med. 2011, 364, 2507-2516. [CrossRef]

12. Hauschild, A.; Grob, J.J.; Demidov, L.V.; Jouary, T.; Gutzmer, R.; Millward, M.; Rutkowski, P.; Blank, C.U.; Miller, W.H., Jr.; Kaempgen, E.; et al. Dabrafenib in BRAF-mutated metastatic melanoma: A multicentre, open-label, phase 3 randomised controlled trial. Lancet (Lond. Engl.) 2012, 380, 358-365. [CrossRef]

13. Flaherty, K.T.; Robert, C.; Hersey, P.; Nathan, P.; Garbe, C.; Milhem, M.; Demidov, L.V.; Hassel, J.C.; Rutkowski, P.; Mohr, P.; et al. Improved survival with MEK inhibition in BRAF-mutated melanoma. N. Engl. J. Med. 2012, 367, 107-114. [CrossRef] [PubMed]

14. Karachaliou, N.; Gonzalez-Cao, M.; Sosa, A.; Berenguer, J.; Bracht, J.W.P.; Ito, M.; Rosell, R. The combination of checkpoint immunotherapy and targeted therapy in cancer. Ann. Transl. Med. 2017, 5, 388. [CrossRef] [PubMed]

15. Hughes, P.E.; Caenepeel, S.; Wu, L.C. Targeted Therapy and Checkpoint Immunotherapy Combinations for the Treatment of Cancer. Trends Immunol. 2016, 37, 462-476. [CrossRef]

16. Frederick, D.T.; Piris, A.; Cogdill, A.P.; Cooper, Z.A.; Lezcano, C.; Ferrone, C.R.; Mitra, D.; Boni, A.; Newton, L.P.; Liu, C.; et al. BRAF inhibition is associated with enhanced melanoma antigen expression and a more favorable tumor microenvironment in patients with metastatic melanoma. Clin. Cancer Res. Off. J. Am. Assoc. Cancer Res. 2013, 19, 1225-1231. [CrossRef] 
17. Taube, J.M.; Anders, R.A.; Young, G.D.; Xu, H.; Sharma, R.; McMiller, T.L.; Chen, S.; Klein, A.P.; Pardoll, D.M.; Topalian, S.L.; et al. Colocalization of inflammatory response with B7-h1 expression in human melanocytic lesions supports an adaptive resistance mechanism of immune escape. Sci. Transl. Med. 2012, 4, $127 \mathrm{ra} 137$. [CrossRef]

18. Wilmott, J.S.; Long, G.V.; Howle, J.R.; Haydu, L.E.; Sharma, R.N.; Thompson, J.F.; Kefford, R.F.; Hersey, P.; Scolyer, R.A. Selective BRAF inhibitors induce marked T-cell infiltration into human metastatic melanoma. Clin. Cancer Res. Off. J. Am. Assoc. Cancer Res. 2012, 18, 1386-1394. [CrossRef]

19. Vella, L.J.; Pasam, A.; Dimopoulos, N.; Andrews, M.; Knights, A.; Puaux, A.L.; Louahed, J.; Chen, W.; Woods, K.; Cebon, J.S. MEK inhibition, alone or in combination with BRAF inhibition, affects multiple functions of isolated normal human lymphocytes and dendritic cells. Cancer Immunol. Res. 2014, 2, 351-360. [CrossRef]

20. Comin-Anduix, B.; Chodon, T.; Sazegar, H.; Matsunaga, D.; Mock, S.; Jalil, J.; Escuin-Ordinas, H.; Chmielowski, B.; Koya, R.C.; Ribas, A. The oncogenic BRAF kinase inhibitor PLX4032/RG7204 does not affect the viability or function of human lymphocytes across a wide range of concentrations. Clin. Cancer Res. Off. J. Am. Assoc. Cancer Res. 2010, 16, 6040-6048. [CrossRef]

21. Rosenberg, S.A.; Packard, B.S.; Aebersold, P.M.; Solomon, D.; Topalian, S.L.; Toy, S.T.; Simon, P.; Lotze, M.T.; Yang, J.C.; Seipp, C.A.; et al. Use of tumor-infiltrating lymphocytes and interleukin-2 in the immunotherapy of patients with metastatic melanoma. A preliminary report. N. Engl. J. Med. 1988, 319, 1676-1680. [CrossRef]

22. Rosenberg, S.A. IL-2: The first effective immunotherapy for human cancer. J. Immunol. (Baltimore, Md. 1950) 2014, 192, 5451-5458. [CrossRef] [PubMed]

23. Amaria, R.N.; Reuben, A.; Cooper, Z.A.; Wargo, J.A. Update on use of aldesleukin for treatment of high-risk metastatic melanoma. Immuno. Targets Ther. 2015, 4, 79-89. [CrossRef]

24. Wei, S.C.; Duffy, C.R.; Allison, J.P. Fundamental Mechanisms of Immune Checkpoint Blockade Therapy. Cancer Discov. 2018, 8, 1069-1086. [CrossRef] [PubMed]

25. Shin, M.H.; Kim, J.; Lim, S.A.; Kim, J.; Kim, S.-J.; Lee, K.-M. NK Cell-Based Immunotherapies in Cancer. Immune Netw. 2020, 20, e17.

26. Ribas, A.; Wolchok, J.D. Cancer immunotherapy using checkpoint blockade. Science (New York, N.Y.) 2018, 359, 1350-1355. [CrossRef]

27. Pardoll, D.M. The blockade of immune checkpoints in cancer immunotherapy. Nat. Rev. Cancer 2012, 12, 252-264. [CrossRef]

28. Krummel, M.F.; Allison, J.P. CD28 and CTLA-4 have opposing effects on the response of T cells to stimulation. J. Exp. Med. 1995, 182, 459-465. [CrossRef]

29. Freeman, G.J.; Long, A.J.; Iwai, Y.; Bourque, K.; Chernova, T.; Nishimura, H.; Fitz, L.J.; Malenkovich, N.; Okazaki, T.; Byrne, M.C.; et al. Engagement of the PD-1 immunoinhibitory receptor by a novel B7 family member leads to negative regulation of lymphocyte activation. J. Exp. Med. 2000, 192, 1027-1034. [CrossRef]

30. Sharpe, A.H.; Wherry, E.J.; Ahmed, R.; Freeman, G.J. The function of programmed cell death 1 and its ligands in regulating autoimmunity and infection. Nat. Immunol. 2007, 8, 239-245. [CrossRef]

31. Fife, B.T.; Pauken, K.E. The role of the PD-1 pathway in autoimmunity and peripheral tolerance. Ann. N. Y. Acad. Sci. 2011, 1217, 45-59. [CrossRef]

32. Topalian, S.L.; Hodi, F.S.; Brahmer, J.R.; Gettinger, S.N.; Smith, D.C.; McDermott, D.F.; Powderly, J.D.; Carvajal, R.D.; Sosman, J.A.; Atkins, M.B.; et al. Safety, activity, and immune correlates of anti-PD-1 antibody in cancer. N. Engl. J. Med. 2012, 366, 2443-2454. [CrossRef] [PubMed]

33. Topalian, S.L.; Sznol, M.; McDermott, D.F.; Kluger, H.M.; Carvajal, R.D.; Sharfman, W.H.; Brahmer, J.R.; Lawrence, D.P.; Atkins, M.B.; Powderly, J.D.; et al. Survival, durable tumor remission, and long-term safety in patients with advanced melanoma receiving nivolumab. J. Clin. Oncol. Off. J. Am. Soc. Clin. Oncol. 2014, 32, 1020-1030. [CrossRef] [PubMed]

34. Popovic, A.; Jaffee, E.M.; Zaidi, N. Emerging strategies for combination checkpoint modulators in cancer immunotherapy. J. Clin. Investig. 2018, 128, 3209-3218. [CrossRef] [PubMed]

35. Khair, D.O.; Bax, H.J.; Mele, S.; Crescioli, S.; Pellizzari, G.; Khiabany, A.; Nakamura, M.; Harris, R.J.; French, E.; Hoffmann, R.M.; et al. Combining Immune Checkpoint Inhibitors: Established and Emerging Targets and Strategies to Improve Outcomes in Melanoma. Front. Immunol. 2019, 10, 453. [CrossRef]

36. Wolchok, J.D.; Kluger, H.; Callahan, M.K.; Postow, M.A.; Rizvi, N.A.; Lesokhin, A.M.; Segal, N.H.; Ariyan, C.E.; Gordon, R.A.; Reed, K.; et al. Nivolumab plus ipilimumab in advanced melanoma. N. Engl. J. Med. 2013, 369, 122-133. [CrossRef] 
37. Atkins, M.B.; Larkin, J. Immunotherapy Combined or Sequenced With Targeted Therapy in the Treatment of Solid Tumors: Current Perspectives. J. Natl. Cancer Inst. 2016, 108, djv414. [CrossRef]

38. ClinicalTrials.gov. Available online: https://clinicaltrials.gov/ (accessed on 20 December 2019).

39. Wang, M.; Liu, Y.; Cheng, Y.; Wei, Y.; Wei, X. Immune checkpoint blockade and its combination therapy with small-molecule inhibitors for cancer treatment. Biochimica Et Biophys. Acta Rev. Cancer 2019, 1871, 199-224. [CrossRef]

40. Shain, A.H.; Bastian, B.C. From melanocytes to melanomas. Nat. Rev. Cancer 2016, 16, 345-358. [CrossRef]

41. Cerezo, M.; Lehraiki, A.; Millet, A.; Rouaud, F.; Plaisant, M.; Jaune, E.; Botton, T.; Ronco, C.; Abbe, P.; Amdouni, H.; et al. Compounds Triggering ER Stress Exert Anti-Melanoma Effects and Overcome BRAF Inhibitor Resistance. Cancer Cell 2016, 29, 805-819. [CrossRef]

42. Ascierto, P.A.; Kirkwood, J.M.; Grob, J.J.; Simeone, E.; Grimaldi, A.M.; Maio, M.; Palmieri, G.; Testori, A.; Marincola, F.M.; Mozzillo, N. The role of BRAF V600 mutation in melanoma. J. Transl. Med. 2012, 10, 85. [CrossRef]

43. Menzies, A.M.; Long, G.V.; Murali, R. Dabrafenib and its potential for the treatment of metastatic melanoma. Drug Des. Dev. Ther. 2012, 6, 391-405. [CrossRef]

44. Xue, Z.; Vis, D.J.; Bruna, A.; Sustic, T.; van Wageningen, S.; Batra, A.S.; Rueda, O.M.; Bosdriesz, E.; Caldas, C.; Wessels, L.F.A.; et al. MAP3K1 and MAP2K4 mutations are associated with sensitivity to MEK inhibitors in multiple cancer models. Cell Res. 2018, 28, 719-729. [CrossRef] [PubMed]

45. Eroglu, Z.; Ribas, A. Combination therapy with BRAF and MEK inhibitors for melanoma: Latest evidence and place in therapy. Ther. Adv. Med Oncol. 2016, 8, 48-56. [CrossRef] [PubMed]

46. Brighton, H.E.; Angus, S.P.; Bo, T.; Roques, J.; Tagliatela, A.C.; Darr, D.B.; Karagoz, K.; Sciaky, N.; Gatza, M.L.; Sharpless, N.E.; et al. New Mechanisms of Resistance to MEK Inhibitors in Melanoma Revealed by Intravital Imaging. Cancer Res. 2018, 78, 542-557. [CrossRef]

47. Shirley, M. Encorafenib and Binimetinib: First Global Approvals. Drugs 2018, 78, 1277-1284. [CrossRef]

48. Zappa, C.; Mousa, S.A. Non-small cell lung cancer: Current treatment and future advances. Transl. Lung Cancer Res. 2016, 5, 288-300. [CrossRef]

49. Siegel, R.L.; Miller, K.D.; Jemal, A. Cancer statistics, 2018. CA Cancer J. Clin. 2018, 68, 7-30. [CrossRef]

50. Herbst, R.S.; Baas, P.; Kim, D.W.; Felip, E.; Perez-Gracia, J.L.; Han, J.Y.; Molina, J.; Kim, J.H.; Arvis, C.D.; Ahn, M.J.; et al. Pembrolizumab versus docetaxel for previously treated, PD-L1-positive, advanced non-small-cell lung cancer (KEYNOTE-010): A randomised controlled trial. Lancet (Lond. Engl.) 2016, 387, 1540-1550. [CrossRef]

51. Janjigian, Y.Y.; Park, B.J.; Zakowski, M.F.; Ladanyi, M.; Pao, W.; D’Angelo, S.P.; Kris, M.G.; Shen, R.; Zheng, J.; Azzoli, C.G. Impact on disease-free survival of adjuvant erlotinib or gefitinib in patients with resected lung adenocarcinomas that harbor EGFR mutations. J. Thorac. Oncol. Off. Publ. Int. Assoc. Study Lung Cancer 2011, 6, 569-575. [CrossRef]

52. Zhong, W.Z.; Wang, Q.; Mao, W.M.; Xu, S.T.; Wu, L.; Shen, Y.; Liu, Y.Y.; Chen, C.; Cheng, Y.; Xu, L.; et al. Gefitinib versus vinorelbine plus cisplatin as adjuvant treatment for stage II-IIIA (N1-N2) EGFR-mutant NSCLC (ADJUVANT/CTONG1104): A randomised, open-label, phase 3 study. Lancet. Oncol. 2018, 19, 139-148. [CrossRef]

53. Lim, S.M.; Hong, M.H.; Kim, H.R. Immunotherapy for Non-small Cell Lung Cancer: Current Landscape and Future Perspectives. Immune Netw. 2020, 20, e10. [CrossRef] [PubMed]

54. Miller, K.D.; Siegel, R.L.; Lin, C.C.; Mariotto, A.B.; Kramer, J.L.; Rowland, J.H.; Stein, K.D.; Alteri, R.; Jemal, A. Cancer treatment and survivorship statistics, 2016. CA Cancer J. Clin. 2016, 66, 271-289. [CrossRef] [PubMed]

55. da Cunha Santos, G.; Shepherd, F.A.; Tsao, M.S. EGFR mutations and lung cancer. Annual Rev. Pathol. 2011, 6, 49-69. [CrossRef] [PubMed]

56. Bray, F.; Ferlay, J.; Soerjomataram, I.; Siegel, R.L.; Torre, L.A.; Jemal, A. Global cancer statistics 2018: GLOBOCAN estimates of incidence and mortality worldwide for 36 cancers in 185 countries. CA Cancer J. Clin. 2018, 68, 394-424. [CrossRef] [PubMed]

57. Huang, D.; Sun, W.; Zhou, Y.; Li, P.; Chen, F.; Chen, H.; Xia, D.; Xu, E.; Lai, M.; Wu, Y.; et al. Mutations of key driver genes in colorectal cancer progression and metastasis. Cancer Metastasis Rev. 2018, 37, $173-187$. [CrossRef] [PubMed]

58. Diaz, L.A., Jr.; Le, D.T. PD-1 Blockade in Tumors with Mismatch-Repair Deficiency. N. Engl. J. Med. 2015, 373, 1979. [CrossRef] 
59. Delord, J.P.; Robert, C.; Nyakas, M.; McArthur, G.A.; Kudchakar, R.; Mahipal, A.; Yamada, Y.; Sullivan, R.; Arance, A.; Kefford, R.F.; et al. Phase I Dose-Escalation and -Expansion Study of the BRAF Inhibitor Encorafenib (LGX818) in Metastatic BRAF-Mutant Melanoma. Clin. Cancer Res. Off. J. Am. Assoc. Cancer Res. 2017, 23, 5339-5348. [CrossRef]

60. Bendell, J.C.; Javle, M.; Bekaii-Saab, T.S.; Finn, R.S.; Wainberg, Z.A.; Laheru, D.A.; Weekes, C.D.; Tan, B.R.; Khan, G.N.; Zalupski, M.M.; et al. A phase 1 dose-escalation and expansion study of binimetinib (MEK162), a potent and selective oral MEK1/2 inhibitor. Br. J. Cancer 2017, 116, 575-583. [CrossRef]

61. Rahib, L.; Smith, B.D.; Aizenberg, R.; Rosenzweig, A.B.; Fleshman, J.M.; Matrisian, L.M. Projecting cancer incidence and deaths to 2030: The unexpected burden of thyroid, liver, and pancreas cancers in the United States. Cancer Res. 2014, 74, 2913-2921. [CrossRef]

62. Korc, M. Driver mutations: A roadmap for getting close and personal in pancreatic cancer. Cancer Biol. Ther. 2010, 10, 588-591. [CrossRef]

63. Ko, A.H.; Bekaii-Saab, T.; Van Ziffle, J.; Mirzoeva, O.M.; Joseph, N.M.; Talasaz, A.; Kuhn, P.; Tempero, M.A.; Collisson, E.A.; Kelley, R.K.; et al. A Multicenter, Open-Label Phase II Clinical Trial of Combined MEK plus EGFR Inhibition for Chemotherapy-Refractory Advanced Pancreatic Adenocarcinoma. Clin. Cancer Res. Off. J. Am. Assoc. Cancer Res. 2016, 22, 61-68. [CrossRef] [PubMed]

64. Bedard, P.L.; Tabernero, J.; Janku, F.; Wainberg, Z.A.; Paz-Ares, L.; Vansteenkiste, J.; Van Cutsem, E.; Perez-Garcia, J.; Stathis, A.; Britten, C.D.; et al. A phase Ib dose-escalation study of the oral pan-PI3K inhibitor buparlisib (BKM120) in combination with the oral MEK1/2 inhibitor trametinib (GSK1120212) in patients with selected advanced solid tumors. Clin. Cancer Res. Off. J. Am. Assoc. Cancer Res. 2015, 21, 730-738. [CrossRef] [PubMed]

65. Tolcher, A.W.; Bendell, J.C.; Papadopoulos, K.P.; Burris, H.A., 3rd; Patnaik, A.; Jones, S.F.; Rasco, D.; Cox, D.S.; Durante, M.; Bellew, K.M.; et al. A phase IB trial of the oral MEK inhibitor trametinib (GSK1120212) in combination with everolimus in patients with advanced solid tumors. Ann. Oncol. Off. J. Eur. Soc. Med. Oncol. 2015, 26, 58-64. [CrossRef] [PubMed]

66. Groenendijk, F.H.; Bernards, R. Drug resistance to targeted therapies: Deja vu all over again. Mol. Oncol. 2014, 8, 1067-1083. [CrossRef]

67. Hodi, F.S.; O’Day, S.J.; McDermott, D.F.; Weber, R.W.; Sosman, J.A.; Haanen, J.B.; Gonzalez, R.; Robert, C.; Schadendorf, D.; Hassel, J.C.; et al. Improved survival with ipilimumab in patients with metastatic melanoma. N. Engl. J. Med. 2010, 363, 711-723. [CrossRef]

68. Ryan, D.P.; Hong, T.S.; Bardeesy, N. Pancreatic adenocarcinoma. N. Engl. J. Med. 2014, 371, $2140-2141$. [CrossRef]

69. Sideras, K.; Braat, H.; Kwekkeboom, J.; van Eijck, C.H.; Peppelenbosch, M.P.; Sleijfer, S.; Bruno, M. Role of the immune system in pancreatic cancer progression and immune modulating treatment strategies. Cancer Treat. Rev. 2014, 40, 513-522. [CrossRef]

70. Robert, C.; Schachter, J.; Long, G.V.; Arance, A.; Grob, J.J.; Mortier, L.; Daud, A.; Carlino, M.S.; McNeil, C.; Lotem, M.; et al. Pembrolizumab versus Ipilimumab in Advanced Melanoma. N. Engl. J. Med. 2015, 372, 2521-2532. [CrossRef]

71. Weber, J.S.; D’Angelo, S.P.; Minor, D.; Hodi, F.S.; Gutzmer, R.; Neyns, B.; Hoeller, C.; Khushalani, N.I.; Miller, W.H., Jr.; Lao, C.D.; et al. Nivolumab versus chemotherapy in patients with advanced melanoma who progressed after anti-CTLA-4 treatment (CheckMate 037): A randomised, controlled, open-label, phase 3 trial. Lancet. Oncol. 2015, 16, 375-384. [CrossRef]

72. Rizvi, N.A.; Mazieres, J.; Planchard, D.; Stinchcombe, T.E.; Dy, G.K.; Antonia, S.J.; Horn, L.; Lena, H.; Minenza, E.; Mennecier, B.; et al. Activity and safety of nivolumab, an anti-PD-1 immune checkpoint inhibitor, for patients with advanced, refractory squamous non-small-cell lung cancer (CheckMate 063): A phase 2, single-arm trial. Lancet. Oncol. 2015, 16, 257-265. [CrossRef]

73. Garon, E.B.; Rizvi, N.A.; Hui, R.; Leighl, N.; Balmanoukian, A.S.; Eder, J.P.; Patnaik, A.; Aggarwal, C.; Gubens, M.; Horn, L.; et al. Pembrolizumab for the treatment of non-small-cell lung cancer. N. Engl. J. Med. 2015, 372, 2018-2028. [CrossRef] [PubMed]

74. Reck, M.; Rodriguez-Abreu, D.; Robinson, A.G.; Hui, R.; Csoszi, T.; Fulop, A.; Gottfried, M.; Peled, N.; Tafreshi, A.; Cuffe, S.; et al. Pembrolizumab versus Chemotherapy for PD-L1-Positive Non-Small-Cell Lung Cancer. N. Engl. J. Med. 2016, 375, 1823-1833. [CrossRef] 
75. Brahmer, J.R.; Tykodi, S.S.; Chow, L.Q.; Hwu, W.J.; Topalian, S.L.; Hwu, P.; Drake, C.G.; Camacho, L.H.; Kauh, J.; Odunsi, K.; et al. Safety and activity of anti-PD-L1 antibody in patients with advanced cancer. N. Engl. J. Med. 2012, 366, 2455-2465. [CrossRef] [PubMed]

76. Chen, A.Y.; Jemal, A.; Ward, E.M. Increasing incidence of differentiated thyroid cancer in the United States, 1988-2005. Cancer 2009, 115, 3801-3807. [CrossRef] [PubMed]

77. Hadoux, J.; Pacini, F.; Tuttle, R.M.; Schlumberger, M. Management of advanced medullary thyroid cancer. Lancet Diabetes Endocrinol. 2016, 4, 64-71. [CrossRef]

78. Cabanillas, M.E.; Zafereo, M.; Gunn, G.B.; Ferrarotto, R. Anaplastic Thyroid Carcinoma: Treatment in the Age of Molecular Targeted Therapy. J. Oncol. Pract. 2016, 12, 511-518. [CrossRef] [PubMed]

79. Khatami, F.; Tavangar, S.M. A Review of Driver Genetic Alterations in Thyroid Cancers. Iran. J. Pathol. 2018, 13, 125-135. [CrossRef]

80. Bikas, A.; Vachhani, S.; Jensen, K.; Vasko, V.; Burman, K.D. Targeted therapies in thyroid cancer: An extensive review of the literature. Expert Rev. Clin. Pharmacol. 2016, 9, 1299-1313. [CrossRef]

(C) 2020 by the authors. Licensee MDPI, Basel, Switzerland. This article is an open access article distributed under the terms and conditions of the Creative Commons Attribution (CC BY) license (http://creativecommons.org/licenses/by/4.0/). 